\title{
GCU
}

Glasgow Caledonian

University

University for the Common Good

\section{Vibrations of metal web joist timber floors with strongbacks}

Zhang, Binsheng; Kermani, Abdy; Fillingham, Tony

Published in:

Structures and Buildings

DOI:

10.1680/jstbu. 14.00130

Publication date:

2016

Document Version

Author accepted manuscript

Link to publication in ResearchOnline

Citation for published version (Harvard):

Zhang, B, Kermani, A \& Fillingham, T 2016, 'Vibrations of metal web joist timber floors with strongbacks', Structures and Buildings, vol. 169, no. 8, pp. 549-562. https://doi.org/10.1680/jstbu.14.00130

\section{General rights}

Copyright and moral rights for the publications made accessible in the public portal are retained by the authors and/or other copyright owners and it is a condition of accessing publications that users recognise and abide by the legal requirements associated with these rights.

Take down policy

If you believe that this document breaches copyright please view our takedown policy at https://edshare.gcu.ac.uk/id/eprint/5179 for details of how to contact us. 


\section{Vibrations of Metal Web Joist Timber Floors with Strongbacks}

(Finally submitted on 01/09/2015; Words: 6909; Figures: 11; Tables: 7)

Author 1

- Binsheng Zhang BEng, MSc, PhD

- Senior Lecturer in Civil and Structural Engineering, School of Engineering and Built Environment, Glasgow Caledonian University, Glasgow, United Kingdom

Author 2

- Abdy Kermani BSc, MSc, PhD, CEng, FIStructE, FIWSc

- Professor of Timber Engineering, the Centre for Timber Engineering (CTE), School of Engineering and the Built Environment, Edinburgh Napier University, Edinburgh, United Kingdom

Author 3

- Tony Fillingham

- Technical Director, MiTek Industries Ltd, Dudley, West Midlands, United Kingdom

Full contact details of the corresponding author

- Binsheng Zhang BEng, MSc, PhD

- Senior Lecturer in Civil and Structural Engineering, School of Engineering and Built Environment, Glasgow Caledonian University, Cowcaddens Road, Glasgow G4 OBA, United Kingdom, Ben.Zhang@gcu.ac.uk 


\section{Abstract}

This research aims to assess the effects of joist spacing, strongbacks and ceiling on the dynamic response of the timber floors with metal web joists so as to evaluate the vibrational design criteria, e.g. modal frequencies, modal shapes, damping and unit point load deflection, required by EC5-1-1 and the UK NA for timber floors. In general, joist spacing, strongbacks and ceiling do not largely influence the fundamental frequency and damping ratio, but affect higher modal frequencies. The measured damping ratio for the fundamental mode is $0.86 \%$ on average. The use of strongback considerably reduces the number of first order modes below 40 $\mathrm{Hz}$, and causes easier fulfilment of velocity design criterion. The test results indicate that the decrease in joist spacing, the increase in number, size and stiffness of strongbacks, and the use of ceiling all largely reduce the maximum displacement of the floors. On average, the calculated displacements based on the equations in the UK National Annex are close to those measured.

\section{Keywords chosen from ICE Publishing list}

Codes of practice \& standards; Dynamics; Timber structures.

\section{List of notations}

a design limit of the deflection of the timber floor under unit point load $(\mathrm{mm} / \mathrm{kN})$

$a_{\text {rms }}$ root-mean-square acceleration

$a_{\mathrm{w}, 95} \quad 95 \%$ fractile weighted acceleration

$B \quad$ width of the floor ( $\mathrm{m}$ or $\mathrm{mm}$ )

$b \quad$ breadth of the strongback $(\mathrm{mm})$

$b_{0} \quad$ parameter for assessing $v$

$(E I)_{\mathrm{B}}$ equivalent plate bending stiffness of the floor about an axis parallel to the joist direction $\left(\mathrm{Nm}^{2} / \mathrm{m}\right)$

$(E I)_{\text {joist }}$ flexural rigidity of the floor joist about an axis perpendicular to the beam direction $\left(\mathrm{Nm}^{2} / \mathrm{m}\right)$, calculated as $(E l)_{\text {joist }}=E_{0, \text { mean }} l_{\mathrm{y}}$

$(E I)\llcorner\quad$ equivalent plate bending stiffness of the floor about an axis perpendicular to the joist direction $\left(\mathrm{Nm}^{2} / \mathrm{m}\right)$ and $(E I)\left\llcorner=E_{0, \text { mean }} l_{y} / s\right.$

$E_{\text {mean }}$ mean elastic modulus of timber materials $\left(\mathrm{N} / \mathrm{m}^{2}\right.$ or $\left.\mathrm{N} / \mathrm{mm}^{2}\right)$

$E_{0} \quad$ elastic modulus parallel to the grain of the floor joist $\left(\mathrm{N} / \mathrm{m}^{2}\right.$ or $\left.\mathrm{N} / \mathrm{mm}^{2}\right)$

$E_{0, \text { mean }}$ mean value of the elastic modulus parallel to the grain of the floor joist $\left(\mathrm{N} / \mathrm{m}^{2}\right.$ or $\left.\mathrm{N} / \mathrm{mm}^{2}\right)$

$F \quad$ unit point load, $F=1 \mathrm{kN}$

$f_{\mathrm{i}, \mathrm{j}} \quad$ vibrational frequency for $\mathrm{i}^{\mathrm{th}}$-order and $\mathrm{j}^{\text {th }}$-mode $(\mathrm{Hz})$

$f_{1} \quad$ fundamental frequency for Mode $1-1(\mathrm{~Hz})$

$h \quad$ depth of the strongback $(\mathrm{mm})$

$I_{y} \quad$ second moment of area about the major axis of the floor joist $\left(\mathrm{m}^{4}\right)$

$k_{\text {amp }} \quad$ amplification factor to account for shear deflections 
$k_{\text {dist }}$ factor to account for proportion of point load distributed to adjacent joists by floor decking

$k_{\text {strut }} \quad$ factor to account for strutting

$L \quad$ span of the floor ( $\mathrm{m}$ or $\mathrm{mm}$ )

$L_{\text {eq }} \quad$ equivalent floor span ( $m$ or $\mathrm{mm}$ )

$m \quad$ mass of the timber floor per unit area $\left(\mathrm{kg} / \mathrm{m}^{2}\right)$

$m_{0} \quad$ mass of the trolley $(\mathrm{kg})$

$m^{\prime} \quad$ equivalent total mass due to the trolley $\left(\mathrm{kg} / \mathrm{m}^{2}\right)$

$m_{0}{ }^{\prime} \quad$ equivalent mass due to the trolley $\left(\mathrm{kg} / \mathrm{m}^{2}\right)$

$n \quad$ number of stronbacks

$n_{40} \quad$ number of first-order modes with natural frequencies up to $40 \mathrm{~Hz}$

$s \quad$ joist spacing of the floor ( $\mathrm{m}$ or $\mathrm{mm}$ )

$t \quad$ thickness of the floor deck or roof ceiling $(\mathrm{mm})$

$v \quad$ unit impulse velocity $\left(\mathrm{m} / \mathrm{Ns}^{2}\right)$

$V_{D V} \quad$ vibration dose value for vertical vibrations

$V_{D V}$ vibration dose value for horizontal vibrations

$V_{\max } \quad$ maximum vibration strength

$v_{\text {rms }} \quad$ root-mean-square velocity

$v_{\mathrm{w}, 95} \quad 95 \%$ fractile weighted velocity

W weight of the joist $(\mathrm{kg})$

w maximum instantaneous vertical deflection under a unit vertical point load $F$ at any point of the floor $(\mathrm{mm} / \mathrm{kN})$

$\zeta_{i, j} \quad$ damping ratio for $\mathrm{i}^{\text {th }}$-order and $\mathrm{j}^{\text {th }}$-mode

$\zeta_{1} \quad$ damping ratio for Mode 1-1

$\rho_{\text {mean }} \quad$ mean density of timber $\left(\mathrm{kg} / \mathrm{m}^{3}\right)$ 


\section{Introduction}

Recently metal web timber joists have been largely used to replace traditional solid timber joists and other engineered joists for constructing floors in low-rise residential houses and long-span floors in commercial buildings. The lightness of timber flanges with the strength of strut steel webs and span far large distances provides more design freedom for both floors and roofs in domestic, industrial and commercial buildings. The metal web joists produced by MiTek Industries Ltd., also called Posi-Joists, are effectively designed using commercial software for constructing floors and roofs (MiTek Industries Ltd, 2012). Top and bottom chords of such joists in the UK are normally manufactured from TR26 solid timber (BSI, 2002), with a height of 47 $\mathrm{mm}$ and a width varying from $72 \mathrm{~mm}$ to $122 \mathrm{~mm}$, forming a series of standard joists (PS8 to PS16 Posi-Joists). Typical joist spacings are $400 \mathrm{~mm}$ and $600 \mathrm{~mm}$. Two or three joists can be put at one location to stiffen and strengthen the floor (Figure 1). Strongbacks as bracings running perpendicular to the joists are often required to transfer the load to adjacent joists. Normally, one strongback is placed at mid-span or two at one-third spans.

In the UK, Eurocode 5 Part 1-1 or EC5-1-1 (BSI, 2004), together with the UK National Annex or UK NA (BSI, 2009), is widely used for design of timber floors constructed with metal web joists, including ultimate and serviceability limit state verifications. The ultimate limit states concern the safety of floor structures and verifications are checked against bending, shear, bearing and lateral stability. The serviceability limit states concern the functioning and appearance of floors under normal use and the comfort of people, and verifications are checked against deflection and vibration. Vibrational criteria often control the design of timber floors, in particular long span floors. The vibrational parameters include fundamental frequency, unit point load deflection and unit impulse velocity response.

In Europe and Canada, research was conducted on assessing the dynamic performance of timber floors and human perception. In the 1980s, Ohlsson (1982) investigated human-induced vibrations of timber floors, and proposed criteria for assessing human comfort by limiting the fundamental frequency, point load deflection and impulse velocity response. His work was adopted in EC5-1-1 for vibrational serviceability design of lightweight timber floors. Chui (1987) conducted field tests to evaluate timber floors using the root-mean-square acceleration (the r.m.s. acceleration) and suggested that the r.m.s. acceleration for design be less than $0.45 \mathrm{~m} / \mathrm{s}^{2}$. $\mathrm{Hu}$ (1992) simulated the dynamic behaviour of ribbed plates by considering shear deformation and rotatory inertia and well predicted the vibrational test results on lightweight I-joist floors. Eriksson (1994) investigated the low frequency forces caused by human activities and developed frequency-domain models based on laboratory measurements. Smith (2003) summarised the serviceability aspects for timber floor vibrations, including human perception of motion, floor response to dynamic loading, avoidance of vibration problems and prediction of floor vibration. Toratti and Talja (2006) announced large dependence of disturbance on various 
vibration sources and proposed body perception scales. Labonnote (2012) studied the damping in timber materials and structures and classified the total damping into material and structural parts. Zhang et al. (2013) summarised current design regulations for comfort assessment of timber floor vibrations in Europe and illustrated design cases of timber floors constructed with solid joists, I-joists and metal web joists. Research work was also conducted in the UK. Zhang et al. investigated the vibrational serviceability performance of timber floors constructed from solid timber joists, I-joists and other engineered joists (Zhang, 2004; Zhang et al., 2005; Bahadori-Jahromi et al., 2006a, 2006b, 2007). Weckendorf et al. studied the vibrational performance of timber floors constructed with l-joists (Weckendorf et al., 2008a, 2008b, 2010; Weckendorf, 2009). Two technical books were also published on timber structural design to Eurocode (McKenzie and Zhang, 1987; Porteous and Kermani, 2012).

Comprehensive study is conducted on the dynamic response of timber floors on behalf of the Metal Web Working Group, comprising ITW Alpine, Gang Nail Systems, MiTek Industries Ltd and Wolf Systems (Zhang et al., 2010). The investigation aims to assess the effects of joist spacing, strongback bracings and ceiling on the dynamic response of the timber floors constructed with metal web joists so as to evaluate the vibrational design criteria given by EC51-1 and the UK NA. The vibrational serviceability performance parameters studied include modal frequencies, in particular the fundamental frequency, modal damping, modal shapes and deflection under unit point load. This paper presents the experimental parts of the investigation and compares with the predicted results using the formulas given in EC5-1-1 and the UK NA.

\section{Experimental programme}

\subsection{Floor configurations}

Nine floor configurations (Floors $\mathrm{A}$ to $\mathrm{I}$ ) are adopted for this test series, with variations of joist spacing, type, size, number and location of strongbacks, and roof ceiling, see Table 1.

\subsection{Floor construction}

All the floors are constructed with WOLF Easi-Joists (PS10) with an overall length of $5.25 \mathrm{~m}$. TR26 solid timber of $47 \mathrm{~mm} \times 97 \mathrm{~mm}$ is used for top and bottom chords and MS250 steel used for webs, giving an overall depth of $254 \mathrm{~mm}$. The mean elastic modulus $E_{0, \text { mean }}$ parallel to the grain for TR26 solid timber chords is determined as $10784 \mathrm{~N} / \mathrm{mm}^{2}$, close to $11000 \mathrm{~N} / \mathrm{mm}^{2}$ given in BS $5268-2$ (BSI, 2002). The mean density of TR26 solid timber for the chords, $\rho_{\text {mean }}$, is $468.46 \mathrm{~kg} / \mathrm{m}^{3}$, close to $450 \mathrm{~kg} / \mathrm{m}^{3}$ given by the manufacturers. The average weight of the joists is $28.11 \mathrm{~kg}$. The deck is formed with $22 \mathrm{~mm}$ T\&G P5 chipboard sheets of $2400 \mathrm{~mm} \times 600 \mathrm{~mm}$ fixed to the metal web joists and to the end bracings, with $8 \mathrm{~g} \times 50 \mathrm{~mm}$ Twinquik Plusdrive steel woodscrews at 300 $\mathrm{mm}$ centres. The mean density of the chipboard sheets, $\rho_{\text {mean }}$ is $621.84 \mathrm{~kg} / \mathrm{m}^{3}$. The C16 timber end bracings of $47 \mathrm{~mm} \times 222 \mathrm{~mm}$ are fixed to both ends of the metal web joists and save cutting 
noggings between the joists. The $\mathrm{C} 16$ solid timber noggings of $47 \mathrm{~mm} \times 72 \mathrm{~mm}$ are fixed to the joists using Cullen UZ/47 clips and $3.75 \mathrm{~mm} \times 30 \mathrm{~mm}$ square twist nails. The $12.5 \mathrm{~mm}$ Gyproc wallboard ceiling sheets are fixed to the joists and noggings with Gyproc screws at $150 \mathrm{~mm}$ centres along the perimeter of the sheets and at $230 \mathrm{~mm}$ centres where ceiling crosses internal joists. The density of the wallboard sheets is $651.39 \mathrm{~kg} / \mathrm{m}^{3}$. The material, size and location of the strongbacks vary with the tests but those strongbacks are fixed to the noggings (Figure 2). The C16 solid timber noggings of $47 \mathrm{~mm} \times 72 \mathrm{~mm}$ are fixed to both chords with $5.0 \mathrm{~mm} \times 100 \mathrm{~mm}$ Speed-Drive steel woodscrews. The strongback is then fixed to the noggins, also tightly against the underside of the top chord, with $3 \mathrm{no} 5.0 \mathrm{~mm} \times 100 \mathrm{~mm}$ Speed-Drive steel woodscrews. Table 2 lists the material properties of the adopted strongbacks measured by Wolf System Ltd.

The tested floors are fixed onto the supporting structures at both ends, forming an effective span of $5.15 \mathrm{~m}$, which are manufactured by Donaldson Timber Engineering and comprise two 2-ply TR26 chord girder walls of $1.2 \mathrm{~m} \times 5.0 \mathrm{~m}$ and ten $45^{\circ}$ triangular outriggers, 5 for each end. The top chords of the walls are manufactured from $47 \mathrm{~mm} \times 147 \mathrm{~mm}$ solid timber and the bottom chords and bracings are from $47 \mathrm{~mm} \times 72 \mathrm{~mm}$ solid timber. The outriggers have a cross-section of $35 \mathrm{~mm} \times 72 \mathrm{~mm}$. All the chord girder walls and outriggers are directly connected to the concrete floor. Figure 3 shows a typical metal web joist floor (Floor F).

\subsection{Vibrational performance testing}

Figure 4 shows the equipment used for vibrational testing. A grid of $5 \times 5=25$ equally distributed node points is drawn on the floor surface served as measurement points and is mirrored in the ARTeMIS Testor software on the laptop screen, used for controlling the vibration tests. Five roving sensors are used to cover all 25 measurement points through 5 measurements. Two additional sensors are placed as references at two pre-fixed locations to capture all vibration modes of interest. The dynamic testing consists of an output-only modal analysis, which is carried out on all metal web joist floors to obtain modal frequencies, damping ratios and modal shapes.

The floor is excited using a $5.0 \mathrm{~kg}$ trolley, including a squared wooden board, four small plastic wheels and a long wooden handle, and loaded with coarse aggregates. During the testing, the trolley is pushed up to the centre of the floor from the edge and pulled back while moving it from one side to other side of the floor, until the floor area is fully excited. The time duration for each measurement is 100 seconds. The accelerometers transform vertical vibrational movements into electrical signals, which are recorded by the data recorder. The recorded signals are then processed using two embedded ARTeMIS Extractor software: the Enhanced Frequency Domain Decomposition (EFDD) and the Stochastic Subspace Identification (SSI). In the EFDD the signals are processed by a Fast Fourier Transform (FFT) to obtain the spectral densities in the frequency domain and an inverse FFT is applied to the densities for estimating modal parameters, while in the SSI a time domain approach is used. Those results obtained by the SSI are presented here due to smaller variations on the studied parameters. Further information 
on the SSI is given by Brincker and Andersen (2006) and Peeters and De Roeck (2001). From this analysis, modal frequencies, modal damping ratios and modal shapes are obtained.

\subsection{Unit point load deflection testing}

All floors are tested to measure the deflection under $1 \mathrm{kN}$ at mid-span of each joist in turn. The equipment used for the point load deflection tests contain LVDTs (Linear Voltage Displacement Transducers) (Figure 5(a)), steel weights, hanger and base plate (Figure 5(b)), and data recorder. The total weight applied is $101.94 \mathrm{~kg}(1.0 \mathrm{kN})$. The data recorder is the 20-channels Instrument Division System 5000, Model 5100 Scanner. Each floor is loaded at mid-span of each joist over an area of $100 \mathrm{~mm} \times 100 \mathrm{~mm}$ using the steel plate. The mid-span deflections are measured using the LVDTs for all joists when each of them is loaded. Thus, nine LVDTs are used for Floors A to F and thirteen LVDTs for Floors G to I. Because of limited LVDTs (up to 15), only six LVDTs are used to measure the deflections at supports for Floors $A$ to $F$, placed at both support ends of Joists 1, 5 and 9 (the most outer joists and central one). Only two LVDTs are used for Floors $\mathrm{G}$ to I, movably placed at both support ends of each loaded joist. All LDVTs are $350 \Omega$ full bridge transducers with an input of $10 \mathrm{~V} A C / D C$, and are calibrated before the deflection tests. All other unmeasured deflections at the support ends of the joists are determined using linear interpolations. Each set of measurements is repeated twice to obtain reliable results.

\section{Vibrational test results and discussion}

Table 3 presents the vibrational test results of all first-order modal frequencies up to $40 \mathrm{~Hz}$ and damping ratios. A first-order mode implies only a half sine wave along the floor span direction. The first subscripts for the frequency $f$ and the damping ratio $\zeta$ represent the number of half sine waves in the floor span direction and the second subscripts represent the number of half sine waves in the transverse direction (along the support direction). In EC5-1-1, a parameter $n_{40}$, the number of first-order modes with natural frequencies up to $40 \mathrm{~Hz}$, is defined for calculating the unit impulse velocity $v$, and the measured $n_{40}$ values are also listed in Table 3 . The smaller the $n_{40}$ value, the better the vibrational performance of the floor. Table 4 lists the frequencies up to $40 \mathrm{~Hz}$ of the second-order modes and damping ratios. The frequencies in the brackets imply those slightly over $40 \mathrm{~Hz}$. The mean values and standard deviations for the damping ratios are also given in the tables. Figure 6 shows the first-order mode shapes of Floor I, and Figure 7 shows the corresponding second-order mode shapes. The floor span and support line directions, noted as $L$ and $T$, are shown in the figures to help understand these mode shapes.

\subsection{Fundamental frequency}

\subsubsection{Joist spacing}

The comparison of the modal frequencies for three sets of floors (Floors $A$ and G; Floors $E$ and $\mathrm{H}$; Floors $\mathrm{F}$ and $\mathrm{I}$ ) with the same configurations but different joist spacings (600 $\mathrm{mm}$ and 400 
$\mathrm{mm}$ ) shows an increase in the first two modal frequencies for the smaller spacing. In particular the increment for the fundamental frequency (Mode 1-1) varies from $0.8 \mathrm{~Hz}$ to $1.1 \mathrm{~Hz}$. For higher modes, the decrease in joist spacing slightly reduces the frequencies for the floors stiffened with strongback only or strongback and ceiling. In general, smaller spacing slightly raises the fundamental frequency as the increased stiffness overwhelms the increased mass.

\subsubsection{Ceiling}

The comparison of the modal frequencies for two sets of floors without or with ceiling (Floors $E$ and $\mathrm{F}$; Floors $\mathrm{H}$ and $\mathrm{I}$ ) shows a decrease in the first two modal frequencies for the floors with ceiling due to the extra weight introduced. The increased stiffness due to the composite effect with ceiling does not compensate the weight increase. Drops of $1.1-1.2 \mathrm{~Hz}$ in the fundamental frequency are observed. For higher modes, the addition of the ceiling increases the frequencies and for Mode 1-6 an increase of up to $2.4 \mathrm{~Hz}$ can be observed.

\subsubsection{Number, size and type of strongbacks}

The comparison of the modal frequencies for two sets of floors (Floors A, E and D; Floors G and $\mathrm{H}$ ) with different numbers of strongbacks shows that the increasing numbers of strongback little affects the first two frequencies but largely influences the higher frequencies. In particular, the use of two strongbacks increases the frequency of the floors with the $600 \mathrm{~mm}$ joist spacing by $4.7 \mathrm{~Hz}$ for Mode $1-4$ and $10.1 \mathrm{~Hz}$ for Mode 1-5. Even one strongback can increase the frequency for Mode 1-6 by $10 \mathrm{~Hz}$ for the floors with different joist spacings. The comparison of the modal frequencies for one set of floors (Floors A, E and B) with different strongback sizes shows that the increasing strongback size has little effect on the first two frequencies but largely influences the higher frequencies. One $35 \mathrm{~mm} \times 97 \mathrm{~mm}$ TR26 strongback put at mid-span raises the floor frequency with $600 \mathrm{~mm}$ joist spacing by $3.5 \mathrm{~Hz}$ for Mode $1-4$ and $6.8 \mathrm{~Hz}$ for

Mode 1-5. However, one $47 \mathrm{~mm} \times 147 \mathrm{~mm}$ TR26 strongback at mid-span increases the frequency for Mode 1-5 by up to $13.4 \mathrm{~Hz}$. Finally, the comparison of the modal frequencies for one set of floors (Floors B and C) with different types of strongback, i.e. $47 \mathrm{~mm} \times 147 \mathrm{~mm}$ TR26 solid timber and $45 \mathrm{~mm} \times 147 \mathrm{~mm}$ Kerto $S$ laminated veneer lumber (LVL), shows similar dynamic behaviours because both strongbacks have similar sizes and stiffnesses. Little difference in frequency for all first-order modes is observed.

\subsubsection{Comparison of the calculated fundamental frequencies to EC5-1-1 with the measured}

In EC5-1-1, the fundamental frequency of residential floors is required to be larger than $8 \mathrm{~Hz}$. For a rectangular floor with dimensions of $L \times B$, simply supported along all four edges, the fundamental frequency $f_{1}$ can be calculated from Equation 7.4 of the code as

1. $f_{1}=\frac{\pi}{2 L^{2}} \sqrt{\frac{(E I)_{\mathrm{L}}}{m}}$ 
where

$(E l)_{\mathrm{L}} \quad$ is the equivalent plate bending stiffness of the floor about an axis perpendicular to the joist $\left(\mathrm{Nm}^{2} / \mathrm{m}\right)$ and is calculated as $(E I)_{\llcorner}=E_{0, \text { mean }} l_{\mathrm{y}} / s$,

$E_{0, \text { mean }}$ is the mean value of the elastic modulus parallel to the grain of the floor joist $\left(\mathrm{N} / \mathrm{m}^{2}\right)$,

$s \quad$ is the joist spacing of the floor $(\mathrm{m})$,

$I_{y} \quad$ is the second moment of area about the major axis of the floor joist $\left(\mathrm{m}^{4}\right)$,

$m \quad$ is the mass of the timber floor per unit area $\left(\mathrm{kg} / \mathrm{m}^{2}\right)$.

The above equation does not include the effect of the trolley with $m_{0}=5 \mathrm{~kg}$ for exciting the floor. To reflect this, Rayleigh's approximation method (Tedesco et al., 1999; Humar, 2012) is used to modify Equation 1 by introducing an equivalent mass $m_{0}{ }^{\prime}=2 m_{0} / L s\left(\mathrm{~kg} / \mathrm{m}^{2}\right)$ due to the trolley. Here the deformed floor shape is assumed to be a half sine wave and the trolley is assumed to act at mid-span of the floor joist considered. Thus, the original floor mass $m$ is modified using an equivalent total mass $m^{\prime}=m+m_{0}^{\prime}$, while the floor stiffness remains the same.

Table 5 lists the calculated fundamental frequency values based on Equation 1 using both $m$ and $m^{\prime}$ for all floors, together with their ratios to the measured values. Figure 8 shows the calculated and measured fundamental frequencies for all floors. On average, the calculated fundamental frequency values, $f_{1, \mathrm{EC} 5}$, are $11 \%$ larger than those measured except Floor $\mathrm{F}$ with

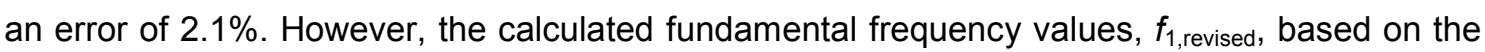
modified mass are only 4\% larger. Actually Equation 1, deduced from beam bending theory, is applicable to floors simply supported along two edges like those tested here. Beside the trolley weight, the support structures may not be fully rigid, making the system less stiff and slightly reducing $f_{1}$. Figure 8 shows that all measured $f_{1}$ values are larger than $8 \mathrm{~Hz}$, indicating that all nine floors are satisfactory with respect to $f_{1}$.

\subsection{Damping}

Damping is an intrinsic structural property of floors and represents the ability to absorb and dissipate kinetic energy. The higher the damping, the more rapidly the vibrational energy dissipates and the better a structure performs. Damping cannot be calculated but can only be determined through experimental testing. In this study, damping is investigated as a parameter for designing metal web joist floors for the serviceability criteria on unit impulse velocity specified in EC5-1-1, with more attention paid to the first-order modal damping ratios. Figure 9 shows the measured values of the Mode 1-1 damping ratio $\zeta_{1,1}$ or simply $\zeta_{1}$ for all nine floors. There is no obvious trend between the measured $\zeta_{1}$ values and the configuration parameters, indicating that $\zeta_{1}$ is only dependent on the floor type. $\zeta_{1}$ varies from $0.77 \%$ to $0.99 \%$ with an average of $0.86 \%$ and a standard deviation of $0.07 \%$. This is less than $50 \%$ of the design value $2 \%$ recommended in the UK NA (BSI, 2004) and smaller than 1\% recommended in EC5-1-1 
(BSI, 2009). In contrast, previous study showed that $\zeta_{1}$ for similar floors constructed with I-joists varied between $2 \%$ and $4 \%$ (Weckendorf, 2008a), much larger than those measured on the metal web joist floors. Table 3 also shows that the average damping ratios for Modes 1-2 and 13 are $0.82 \%$ and $0.94 \%$, both below $1 \%$. For Modes $1-4$ to $1-6$, the damping ratios vary from $1.18 \%$ to $1.28 \%$, slightly larger than $1 \%$. Table 4 shows that the average damping ratios for the first two second-order modes, Modes $2-1$ and $2-2$, are $1.73 \%$ and $1.86 \%$, both below $2 \%$.

In this investigation, an average damping ratio of $0.86 \%$ for $\zeta_{1}$ is accurately measured for the tested metal web joist floors under lab conditions using the comprehensive testing facilities and sophisticated software. In practice, situations could be much worse due to variations in floor geometries, available testing facilities, utilised analysing software, etc., and also due to the difficulties in repeatability. Therefore a damping ratio of $0.9 \%$ or simply $1 \%$ is recommended for structural design and analysis of metal web joist floors.

\subsection{Unit impulse velocity response}

For timber floor design, the velocity response under unit impulse, $v$, is used to assess the vibrational serviceability performance. From Clause 7.3.3 in EC5-1-1, for residential floors with a fundamental frequency greater than $8 \mathrm{~Hz}$, Equation 7.4 should be verified

2. $v \leq b_{0}{ }^{\left(\mathrm{f}_{1} \zeta-1\right)}$

where $v\left(\mathrm{~m} / \mathrm{Ns}^{2}\right)$, the maximum initial value of the vertical floor vibration velocity $(\mathrm{m} / \mathrm{s})$ caused by a unit impulse $1.0 \mathrm{Ns}$, can be determined from Equation 7.6 of EC5-1-1 as

3. $\quad v=\frac{4\left(0.4+0.6 n_{40}\right)}{m B L+200}\left(\mathrm{~m} / \mathrm{Ns}^{2}\right)$

where

$b_{0} \quad$ is a parameter for assessing $v$ and can be determined from Figure 7.2 in EC5-1-1,

$f_{1}$ is the fundamental frequency and is obtained from Equation 7.4 in EC5-1-1 or Equation 1, $\zeta \quad$ is the damping ratio, recommended as $\zeta=0.01$ in EC5-1-1 and $\zeta=0.02$ in the UK NA.

The parameter $n_{40}$ can be calculated from Equation 7.7 of EC5-1-1 as

4. $\quad n_{40}=\left\{\left[\left(\frac{40}{f_{1}}\right)^{2}-1\right]\left(\frac{B}{L}\right)^{4} \frac{(E I)_{\mathrm{L}}}{(E I)_{\mathrm{B}}}\right\}^{0.25}$ 
where $(E I)_{B}$ is the equivalent plate bending stiffness of the floor about an axis parallel to the beam $\left(\mathrm{Nm}^{2} / \mathrm{m}\right)$, gained by superpositioning the individual stiffnesses according to the UK NA as

5. $\quad(E I)_{\mathrm{B}}=\frac{E_{0, \text { mean, } \mathrm{P5}} t_{\mathrm{P} 5}^{3}}{12}+\frac{E_{\text {plasterboard }} t_{\text {plasterboard }}^{3}}{12}+\frac{E_{\text {strongback }} b_{\text {strongback }} h_{\text {strongback }}^{3}}{12 L}$

Here, the symbol $E$ stands for the elastic modulus, $b$ for the breadth, $t$ for the thickness and $h$ for the depth, and the subscript P5 implies the P5 chipboards. The unit impulse velocity could not be directly measured, but Equation 3 shows that the rise in $n_{40}$ always unfavourably leads to a larger $v$. The smaller the value of $n_{40}$, the smaller $v$ and the better vibrational performance of the floor. Thus $n_{40}$ can be indirectly used to assess the vibrational performance of a floor. Table 6 lists the calculated values of $v$ and $n_{40}$ for the floors with joist spacings of $600 \mathrm{~mm}$ (Floors A to $\mathrm{F}$ ) and $400 \mathrm{~mm}$ (Floors $\mathrm{G}$ to I). The ratios of the unit impulse velocity $v$ to the design limit $b^{\left(\mathrm{f}_{1} \zeta-1\right)}$ are also included. When this ratio is larger than 1.0, the design will fail to pass the criterion.

The comparison of the calculated $n_{40}$ values with the measured ones shows that the differences between them for all floors are less than one, indicating that Equation 7.7 of EC5-1-1 can well predict $n_{40}$ so as to assess the vibrational performance of the floor. Compared with Floor $\mathrm{A}$ with $600 \mathrm{~mm}$ joist spacing and Floor $\mathrm{G}$ with $400 \mathrm{~mm}$ joist spacing, the measured and calculated results show that the use of strongbacks significantly reduces $n_{40}$. The stiffer the strongback, the lower $n_{40}$ and the better vibrational performance of the floor (Floors $B$ to $E$ vs Floor $A$ ). The use of $47 \mathrm{~mm} \times 147 \mathrm{~mm}$ TR26 solid timber (Floor B) and $45 \mathrm{~mm} \times 147 \mathrm{~mm}$ Kerto S LVL (Floor C) causes the lowest $n_{40}$. The measured $n_{40}$ decreases from 8 for the floor without strongbacks and ceiling, with $600 \mathrm{~mm}$ joist spacing (Floor A), to 5 (Floors B and C), down by 3 . The use of ceiling together with strongbacks (Floors $\mathrm{F}$ and $\mathrm{I}$ ) lowers the measured $n_{40}$ from 8 to 6 , down by 2 . No difference is found in the measured $n_{40}$ values for the floors with or without ceiling but with strongbacks (Floor $\mathrm{E}$ vs Floor $\mathrm{F}$; Floor $\mathrm{H}$ vs Floor I). Larger number of strongbacks decreases the measured $n_{40}$ (Floor $\mathrm{D}$ vs Floors $\mathrm{E}$ and $\mathrm{A}$ ) but the larger joist spacing slightly increases the measured $n_{40}$ (Floor A vs Floor G; Floor E vs Floor H; Floor F vs Floor I).

Figure 10 illustrates the calculated unit impulse velocities of all floors based on the calculated $n_{40}$ values, together with the design limits in EC5-1-1 and the UK NA. The comparison shows that all floors satisfy the criteria for unit impulse velocity set in the UK NA and all floors satisfy the criteria set in EC5-1-1 except Floor A which has no strongbacks and ceiling and with 600 $\mathrm{mm}$ joist spacing. The results also show that the use of strongbacks can significantly reduce $v$. The stiffer the strongback, the lower $v$ and the better vibrational performance of the floor (Floors $B$ to $E$ vs Floor A). The use of $47 \mathrm{~mm} \times 147 \mathrm{~mm}$ TR26 solid timber (Floor B) and $45 \mathrm{~mm} \times$ $147 \mathrm{~mm}$ Kerto S LVL (Floor C) shows the largest reduction in $v$, down from $0.0238 \mathrm{~m} / \mathrm{Ns}^{2}$ to $0.0137 \mathrm{~m} / \mathrm{Ns}^{2}$ and $0.0135 \mathrm{~m} / \mathrm{Ns}^{2}$ or down by $42.2 \%$ and $43.1 \%$. The addition of the ceiling 
decreases $v$ compared with the floors without or even with strongbacks (Floor $F$ vs Floors $A$ and $E$; Floor I vs Floors $G$ and $H$ ). Larger number of strongbacks decreases $v$ (Floor $D$ vs Floors $E$ and A). As expected, joist spacing also affects $v$. The smaller the joist spacing, the lower $v$ (Floor A vs Floor G; Floor E vs Floor H; Floor F vs Floor I).

On the other hand, the design limit for unit impulse velocity given in the UK NA is very relaxed compared with that given in EC5-1-1 because the former adopts a higher damping ratio of $2 \%$. In this investigation, however, an average damping ratio of $0.86 \%$ is observed for the tested metal web joist floors. Hence, a damping ratio of $1 \%$ given in EC5-1-1 may be a better option for the metal web joist floors, but the adoption of $\zeta=1 \%$ will tighten the design limit.

\section{Unit point load deflection test results and discussion}

Table 7 and Figure 11 illustrate the measured maximum displacements of all floors under $1 \mathrm{kN}$.

\subsection{Joist spacing}

For the same floor configuration, a reduction in joist spacing significantly lowers the maximum displacement $w$. For the floors without strongback and ceiling (Floors $A$ and $G$ ), $w$ decreases from $1.80 \mathrm{~mm}$ to $1.44 \mathrm{~mm}$, down by $0.36 \mathrm{~mm}$ or $20 \%$. For the floors with strongback but without ceiling (Floors $E$ and $H$ ), $w$ decreases from $1.25 \mathrm{~mm}$ to $0.96 \mathrm{~mm}$, down by $0.29 \mathrm{~mm}$ or $23.2 \%$. For the floors with strongback and ceiling (Floors $F$ and I), $w$ decreases from $0.97 \mathrm{~mm}$ to 0.86 $\mathrm{mm}$, down by $0.11 \mathrm{~mm}$ or $11.3 \%$, not as much as those for the floors without ceiling.

\subsection{Ceiling}

The introduction of ceiling largely enhances the floor stiffness and reduces the displacement. For the floors with $600 \mathrm{~mm}$ joist spacing (Floors $E$ and $F$ ), $w$ decreases from $1.25 \mathrm{~mm}$ to 0.97 $\mathrm{mm}$, down by $0.28 \mathrm{~mm}$ or $22.4 \%$. For the floors with $400 \mathrm{~mm}$ joist spacing (Floors $\mathrm{H}$ and $\mathrm{I}$ ), $w$ decreases from $0.96 \mathrm{~mm}$ to $0.86 \mathrm{~mm}$, down by $0.10 \mathrm{~mm}$ or $10.4 \%$, not as significant as those with $600 \mathrm{~mm}$ joist spacing.

\subsection{Number, size and type of strongbacks}

The use of strongbacks significantly enhances the floor stiffness and lowers the maximum displacement. For the floors with $600 \mathrm{~mm}$ joist spacing (Floors $\mathrm{A}, \mathrm{E}$ and $\mathrm{D}$ ), $w$ decreases from $1.80 \mathrm{~mm}$ to $1.25 \mathrm{~mm}$ for the floor with one strongback at mid-span (Floor E) and to $1.28 \mathrm{~mm}$ for the floor with two strongbacks at third-spans (Floor D), down by $0.55 \mathrm{~mm}$ and $0.52 \mathrm{~mm}$ or $30.5 \%$ and $28.9 \%$, indicating that the enhancing effectiveness of stiffness largely depends on the location the strongback situates. The nearer the strongback is to mid-span, the more effective the stiffness enhancement. For the floors with $400 \mathrm{~mm}$ joist spacing (Floors $\mathrm{G}$ and $\mathrm{H}$ ), $w$ decreases from $1.44 \mathrm{~mm}$ to $0.96 \mathrm{~mm}$, down by $0.48 \mathrm{~mm}$ or $33.3 \%$. The increase in the strongback size greatly enhances the floor stiffness and lowers $w$ when the strongbacks are 
placed at the same location. For the floors with $600 \mathrm{~mm}$ joist spacing (Floors A, E and B), w decreases from $1.80 \mathrm{~mm}$ to $1.25 \mathrm{~mm}$ for the floor with a TR26 strongback of $35 \mathrm{~mm} \times 97 \mathrm{~mm}$ at mid-span (Floor E) and to $1.11 \mathrm{~mm}$ for the floor with a TR26 strongback of $47 \mathrm{~mm} \times 147 \mathrm{~mm}$ at mid-span (Floor B), down by $0.55 \mathrm{~mm}$ and $0.69 \mathrm{~mm}$ or $30.5 \%$ and $38.3 \%$. In this study, because two larger strongbacks have similar sizes and stiffnesses, little variation in $\mathrm{w}$ is expected, 1.11 mm Floor B versus $1.08 \mathrm{~mm}$ for Floor C.

\subsection{Comparison of the calculated maximum displacements to EC5-1-1 and the UK NA with those measured}

EC5-1-1 specifies that the deflection of the timber floor under $1 \mathrm{kN}, w$, should satisfy:

$\underline{6 .}$ $w \leq a$

where

$w \quad$ is the maximum instantaneous vertical deflection under $F=1 \mathrm{kN}(\mathrm{mm} / \mathrm{kN})$,

$a \quad$ is the design limit of the deflection of the timber floor under $F(\mathrm{~mm} / \mathrm{kN})$.

Using Equation NA.1 in the UK NA, the floor deflection, $w$, should be calculated as

7. $\quad w=\frac{1000 k_{\mathrm{dist}} L_{\mathrm{eq}}{ }^{3} k_{\mathrm{amp}}}{48(E I)_{\mathrm{joist}}}(\mathrm{mm} / \mathrm{kN})$

where

$k_{\text {dist }}$ is the factor to account for proportion of point load distributed to adjacent joists by floor decking, and is calculated as

$k_{\text {dist }}=\max \left\{k_{\text {strut }}\left[0.38-0.08 \ln \left[14(E I)_{\mathrm{B}} / s^{4}\right]\right] ; 0.30\right\}$,

$k_{\text {strut }}$ is a factor to account for strutting and $k_{\text {strut }}=0.97$ for single or multiple lines of strutting otherwise $k_{\text {strut }}=1.0$,

$(E I)_{B}$ is the equivalent plate bending stiffness of the floor about an axis parallel to the joist direction $\left(\mathrm{Nm}^{2} / \mathrm{m}\right)$, calculated as $(E I)_{\mathrm{B}}=E_{0, \text { mean, } \mathrm{P} 5} t^{3} / 12$,

$L_{\text {eq }}$ is the equivalent floor span $(\mathrm{mm})$ and $L_{\text {eq }}=L$ for simply supported single span joists,

$k_{\text {amp }}$ is an amplification factor to account for shear,

$(E)_{\text {joist }}$ is the flexural rigidity of the floor joist about an axis perpendicular to the joist direction $\left(\mathrm{Nm}^{2} / \mathrm{m}\right)$, calculated as $(E I)_{\text {joist }}=E_{0, \text { mean }} l_{\mathrm{y}}$.

The UK NA to EC5-1-1 also recommends for $(E I)_{\mathrm{B}}$ :

- $(E I)_{\mathrm{B}}$ is calculated as the flexural rigidity of the floor decking perpendicular to the joists, using $E_{\text {mean }}$ for $E$. 
- $(E I)_{\mathrm{B}}$ may be increased by adding the flexural rigidity of plasterboard ceilings fastened directly to the soffit of the floor joists, assuming $E_{\text {plasterboard }}=2000 \mathrm{~N} / \mathrm{mm}^{2}$.

- $(E I)_{\mathrm{B}}$ may be increased for open web joists with a continuous transverse bracing member fastened to all the joists within $0.1 \mathrm{~L}$ of mid-span, by adding the bending stiffness of the transverse member $\left(\mathrm{Nmm}^{2}\right)$ divided by the span $L(\mathrm{~m})$.

The design deflection limit for the timber floor under unit point load, $a$, can be determined based on Table NA.5 in the UK NA as

8. $\quad a=\left\{\begin{array}{cl}1.80 \mathrm{~mm} / \mathrm{kN} & \text { For spans } \leq 4000 \mathrm{~mm} \\ 16500 / L^{1,1} \mathrm{~mm} / \mathrm{kN} & \text { For spans }>4000 \mathrm{~mm}\end{array}\right.$

Table 7 also lists the calculated maximum displacements to Equation NA.1 of the UK NA for the metal web joist floors, together with the design limit $a=1.36 \mathrm{~mm}$. Figure 11 shows the calculated $w$ values for all floors. On average, the calculated values are only $2 \%$ larger than those measured. However, variations between the calculated and measured values are very large, from $-16.1 \%$ (Floor $\mathrm{G}$ ) to $+31.1 \%$ (Floor $\mathrm{F}$ ). There is no clear trend between the calculated and measured maximum displacements. Clearly, all the floors with strongbacks are adequate to the serviceability requirements except two floors without strongbacks, indicating for the current span, strongbacks are needed to evenly distribute the floor loading and lower $w$.

It should be pointed out that a good serviceability design of timber floors should also consider human perception of floor vibrations. For this purpose, various vibrational parameters have been proposed and the limits been set up, e.g. the root-mean-square velocity and acceleration, $v_{\text {rms }}$ and $a_{\text {rms }}$, the $95 \%$ fractile weighted velocity and acceleration, $v_{w, 95}$ and $a_{w, 95}$, the maximum vibration strength $V_{\max }$, the vibration dose values for vertical and horizontal vibrations, $V_{D V} V_{b}$ and $V D V_{d}$, etc. A large damping in timber floors no doubt will lower the peak values of these parameters and help a satisfactory design. This has been extensively explored in another paper by the first author and researchers from other European countries (Zhang et al., 2013).

\section{Conclusions}

Experimental investigations are conducted on the vibrational performance of nine metal web joist floors enhanced with strongbacks. Modal frequencies, modal damping ratios and unit point load displacements are measured and analysed for various joist spacing, number, size, location and type of strongbacks, and ceiling. The measured parameters are compared with the calculated ones based on EC5-1-1 and the UK NA. 
Joist spacing, strongback bracings and ceiling do not largely influence the fundamental frequency but affect higher modal frequencies. All the tested floors have fundamental frequencies over $14 \mathrm{~Hz}$ which are greater than the design threshold of $8 \mathrm{~Hz}$ set in EC5-1-1.

Joist spacing, strongback bracings and ceiling do not largely influence the damping ratios of the lower modes. The damping ratio of the fundamental mode is measured as $0.86 \%$ on average, which is slightly below $1 \%$ recommended in EC5-1-1 and much smaller than $2 \%$ recommended in the UK NA. Therefore, the former may be a better design option for metal web joist floors. The value suggested in EC5-1-1 should only be taken if no other values could be found.

The increase in number and size of strongbacks largely decreases the number of first-order modes with natural frequencies up to $40 \mathrm{~Hz}$, which in turn significantly decreases the unit impulse velocity and thus helps easier fulfilment of the velocity design criterion. Hence, strongbacks should be used to enhance the vibrational performances of timber floors, with respect to velocity response.

Joist spacing, strongback bracings and ceiling largely influence the maximum displacement of metal web joist floors under unit point load. The decrease in joist spacing, the increase in number and size of strongbacks, and the use of ceiling all significantly reduce the maximum displacement. On average, the calculated maximum displacements based on the equations given in the UK NA are close to those measured. All tested floors except one without strongback and ceiling, have the maximum displacements below the limit set by the UK NA.

Due to the limitations of time and cost, only nine floors are tested. Numerical simulations are being conducted at Glasgow Caledonian University on the effects of other geometric configurations on the vibrational serviceability performance of metal web joist floors and roofs, e.g. metal web joist sizes, more arrangements of strongbacks, various floor decks, etc., and the results will be reported when available.

\section{Acknowledgements}

The Metal Web Working Group, comprising ITW Alpine, Gang Nail Systems, MiTek Industries Ltd and Wolf Systems, are greatly appreciated for their support. Dr. Jan Weckendorf, from the Wood Science and Technology Centre at University of New Brunswick, Canada, has fully helped floor vibration testing, data collection and modal analysis while reading his $\mathrm{PhD}$ degree at Edinburgh Napier University. Mr. Willie Lang and Mr. Roshan Dhonju of Edinburgh Napier University have largely assisted in floor construction and modification, together with vibration and displacement tests on the floors. 


\section{References}

Bahadori-Jahromi A, Kermani A, Zhang B, Harte A, Walford B, Bayne K and Turner J (2006a) Influence of geometrical profiles on the structural properties of engineered composite timber beams. Proceedings of the Institution of Civil Engineers, Journal of Buildings \& Structures 159(SB2): 103-114.

Bahadori-Jahromi A, Zhang B, Harte A, Walford B, Bayne K and Turner J (2006b) Investigating the structural performance of multi-webs I-beams, Journal of the Institute of Wood Science 17(3): 148-158.

Bahadori-Jahromi A, Kermani A and Zhang B (2007) A parametric evaluation of the multiwebbed composite joists based on EC5. Journal of the Institute of Wood Science 17(6): 295310.

Brincker R and Andersen P (2006) Understanding stochastic subspace identification. In Proceedings of the 24th International Modal Analysis Conference (IMAC). St. Louis, Missouri, USA.

BSI (2002) BS 5268-2 Structural use of timber. Code of practice for permissible stress design, Materials and workmanship. BSI, London, UK.

BSI (2004) BS EN 1995-1-1:2004 + A1:2008 Eurocode 5: Design of timber structures - Part 11: General - Common rules and rules for buildings. BSI, London, UK.

BSI (2009) NA to BS EN 1995-1-1:2004 + A1:2008 UK National Annex to Eurocode 5: Design of timber structures - Part 1-1: General - Common rules and rules for buildings. BSI, London, UK.

Chui YH (1987) Vibrational Performance of Wooden Floors in Domestic Dwellings. PhD Thesis, Brighton University, Brighton, UK.

Eriksson PE (1994) Vibration of Low-Frequency Floors - Dynamic Forces and Response Prediction. PhD Thesis, Chalmers University of Technology, Göteborg, Sweden.

Hu LJ (1992) Prediction of Vibration Responses of Ribbed Plates by Modal Synthesis. PhD Thesis, The University of New Brunswick, New Brunswick, Canada.

Humar J (2012) Structural Dynamics (3rd Edition). Taylor \& Francis Group, London, UK.

Labonnote N (2012) Damping in Timber Structures. PhD Thesis. Norwegian University of Science and Technology, Trondheim, Norway.

Ljunggren F (2006) Floor Vibration - Dynamic Properties and Subjective Perception. PhD Thesis. Luleå University of Technology, Luleå, Sweden.

McKenzie WMC and Zhang B (2007) Design of Structural Timber to Eurocode 5 (2nd Edition). Basingstoke: Palgrave MacMillan, UK.

MiTek Industries Ltd (2012) Separating Floor Applications, The Posi-StrutTM Technical Handbook - The World of Floor Technology. Dudley, England.

Ohlsson SV (1982) Floor Vibration and Human Discomfort. PhD Thesis, Department of Structural Engineering, Division of Steel and Timber Structures. Chalmers University of Technology, Göteborg, Sweden. 
Peeters B and De Roeck G (2001) Stochastic system identification for operational modal analysis: a review. Journal of Dynamic Systems, Measurement and Control 123: 659-67.

Porteous J and Kermani A (2012) Structural Timber Design to Eurocode 5 (2nd Edition). Wiley-Blackwell, Oxford, UK.

Smith I (2003) Vibrations of timber floors: Serviceability aspects. In Timber Engineering, Edited by Thelandersson S and Larsen HJ. John Wiley \& Sons, 241-266.

Tedesco JW, McDougal WG and Ross CA (1999) Structural Dynamics - Theory and Applications (1st Edition). Addison Wesley Longman, Inc., USA.

Toratti T and Talja A (2006) Classification of human induced floor vibrations. Journal of Building Acoustics 13(3): 211-221.

Weckendorf J, Zhang B, Kermani A and Reid D (2008a) Damping characteristics of timber flooring systems. In Proceedings of the 10th World Conference on Timber Engineering (WCTE-10). Miyazaki, Japan.

Weckendorf J, Zhang B, Kermani A, Reid D (2008b) Effects of mass and local stiffening on the dynamic performance of timber floors. In Proceedings of the 10th World Conference on Timber Engineering (WCTE-10). Miyazaki, Japan.

Weckendorf J (2009) Dynamic Response of Structural Timber Flooring Systems. PhD thesis. Edinburgh Napier University, Edinburgh, UK.

Weckendorf J, Zhang B, Kermani A and Reid D (2010) Finite element modelling of I-joist timber flooring systems to predict modal frequencies, modal shapes and static point load deflections. In Proceedings of the 11th World Conference on Timber Engineering (WCTE11). Riva del Garda, Trentino, Italy.

Zhang B. (2004) Parametric Study on the Design of Timber Floor Joists to Eurocode 5 and National Annex. Technical document for BSI Technical Committee B/525/5, BSI, London, UK.

Zhang B, Bahadori-Jahromi A and Kermani A (2005) Influence of EC5 and the UK National Annex on the Design of Timber Flooring Systems Built with Multi-Webbed Engineered Joists and Solid Timber Joists. Technical document for BSI Technical Committee B/525/5, BSI, London, UK.

Zhang B, Weckendorf J and Kermani A (2010) Vibrational performance of metal-webbed timber floors. In Proceedings of the 11th World Conference on Timber Engineering (WCTE11). Riva del Garda, Trentino, Italy.

Zhang B, Rasmussen B, Jorissen A and Harte A (2013) Comparison of vibrational comfort assessment criteria for design of timber floors among the European countries. Engineering Structures 52: 592-607. 
Table 1. Tested floors with various configurations

\begin{tabular}{cclc}
\hline Floor & $\begin{array}{c}\text { Joist } \\
\text { spacing } \\
s(\mathrm{~mm})\end{array}$ & \multicolumn{1}{c}{ Strongback } & Ceiling \\
\hline A & 600 & None & None \\
B & 600 & $47 \mathrm{~mm} \times 147 \mathrm{~mm}$ TR26 solid timber at mid-span & None \\
C & 600 & $45 \mathrm{~mm} \times 147 \mathrm{~mm}$ Kerto LVL at mid-span & None \\
D & 600 & $35 \mathrm{~mm} \times 97 \mathrm{~mm}$ TR26 solid timber at one-third & None \\
E & 600 & $35 \mathrm{~mm} \times 97 \mathrm{~mm}$ TR26 solid timber at mid-span & None \\
F & 600 & $35 \mathrm{~mm} \times 97 \mathrm{~mm}$ TR26 solid timber at mid-span & Yes \\
G & 400 & None & None \\
H & 400 & $35 \mathrm{~mm} \times 97 \mathrm{~mm}$ TR26 solid timber at mid-span & None \\
I & 400 & $35 \mathrm{~mm} \times 97 \mathrm{~mm}$ TR26 solid timber at mid-span & Yes \\
\hline
\end{tabular}

Table 2. Material properties of the adopted strongbacks

\begin{tabular}{lccccc}
\hline \multicolumn{1}{c}{ Strongback } & $\begin{array}{c}\text { Reference } \\
\text { number }\end{array}$ & $\begin{array}{c}\text { Length } \\
(\mathrm{mm})\end{array}$ & $\begin{array}{c}\text { Weight } \\
W(\mathrm{~kg})\end{array}$ & $\begin{array}{c}\text { Stiffness } \\
E_{0} \\
\left(\mathrm{~N} / \mathrm{mm}^{2}\right)\end{array}$ & $\begin{array}{c}\text { Density } \\
\rho\left(\mathrm{kg} / \mathrm{m}^{3}\right)\end{array}$ \\
\hline $35 \mathrm{~mm} \times 97 \mathrm{~mm}$ TR26 & 1 & 4910 & 8.35 & 10810 & 482 \\
$35 \mathrm{~mm} \times 97 \mathrm{~mm}$ TR26 & 2 & 4910 & 8.40 & 11456 & 485 \\
$35 \mathrm{~mm} \times 97 \mathrm{~mm}$ TR26 & 3 & 4910 & 9.25 & 12625 & 534 \\
$35 \mathrm{~mm} \times 97 \mathrm{~mm}$ TR26 & 4 & 4910 & 8.35 & 12057 & 482 \\
$47 \mathrm{~mm} \times 147 \mathrm{~mm}$ & 5 & 4910 & 16.20 & 12669 & 460 \\
TR26 & & & & & \\
$45 \mathrm{~mm} \times 147 \mathrm{~mm}$ & 6 & 4910 & 17.00 & 11200 & 492 \\
Kerto S & & & & & \\
\hline
\end{tabular}


Table 3. Frequencies and damping ratios of first-order modes for frequencies up to $40 \mathrm{~Hz}$

\begin{tabular}{|c|c|c|c|c|c|c|c|c|c|}
\hline Floor & $\begin{array}{c}f_{1,1} \\
(\mathrm{~Hz})\end{array}$ & $\begin{array}{l}\zeta_{1,1} \\
(\%)\end{array}$ & $\begin{array}{c}f_{1,2} \\
(\mathrm{~Hz})\end{array}$ & $\begin{array}{l}\zeta_{1,2} \\
(\%)\end{array}$ & $\begin{array}{c}f_{1,3} \\
(\mathrm{~Hz})\end{array}$ & $\begin{array}{l}\zeta_{1,3} \\
(\%)\end{array}$ & $\begin{array}{c}f_{1,4} \\
(\mathrm{~Hz})\end{array}$ & $\begin{array}{l}\zeta_{1,4} \\
(\%)\end{array}$ & \\
\hline$A$ & 14.4 & 0.88 & 16.0 & 0.95 & 18.1 & 0.79 & 20.6 & 0.88 & \\
\hline$B$ & 14.6 & 0.83 & 16.2 & 0.70 & 21.2 & 1.08 & 28.4 & 1.03 & \\
\hline$C$ & 14.6 & 0.88 & 16.2 & 0.77 & 21.3 & 0.91 & 28.3 & 1.34 & \\
\hline$D$ & 14.5 & 0.87 & 16.2 & 0.80 & 20.1 & 0.85 & 25.3 & 1.15 & \\
\hline$E$ & 14.5 & 0.79 & 16.2 & 0.83 & 19.6 & 0.90 & 24.1 & 1.43 & \\
\hline$F$ & 13.4 & 0.99 & 15.5 & 0.85 & 19.8 & 0.83 & 25.1 & 1.38 & \\
\hline$G$ & 15.5 & 0.77 & 17.0 & 1.05 & 18.8 & 1.13 & 21.0 & 1.39 & \\
\hline $\mathrm{H}$ & 15.5 & 0.94 & 17.0 & 0.73 & 19.9 & 1.01 & 24.0 & 1.11 & \\
\hline 1 & 14.3 & 0.80 & 16.2 & 0.73 & 19.7 & 0.98 & 24.7 & 1.19 & \\
\hline Mean & & 0.86 & & 0.82 & & 0.94 & & 1.21 & \\
\hline SD & & 0.07 & & 0.11 & & 0.12 & & 0.19 & \\
\hline Floor & $\begin{array}{c}f_{1,5} \\
(\mathrm{~Hz})\end{array}$ & $\begin{array}{l}\zeta_{1,5} \\
(\%)\end{array}$ & $\begin{array}{c}f_{1,6} \\
(\mathrm{~Hz})\end{array}$ & $\begin{array}{l}\zeta_{1,6} \\
(\%)\end{array}$ & $\begin{array}{c}f_{1,7} \\
(\mathrm{~Hz})\end{array}$ & $\begin{array}{l}\zeta_{1,7} \\
(\%)\end{array}$ & $\begin{array}{c}f_{1,8} \\
(\mathrm{~Hz})\end{array}$ & $\begin{array}{l}\zeta_{1,8} \\
(\%)\end{array}$ & $n_{40}$ \\
\hline$A$ & 23.7 & 1.03 & 27.3 & 0.85 & 31.3 & 1.18 & 35.3 & 1.20 & 8 \\
\hline$B$ & 37.1 & 1.15 & - & - & - & - & - & - & 5 \\
\hline$C$ & 37.1 & 1.30 & - & - & - & - & - & - & 5 \\
\hline$D$ & 33.8 & 1.29 & - & - & - & - & - & - & 5 \\
\hline$E$ & 30.5 & 1.37 & 37.2 & 1.40 & - & - & - & - & 6 \\
\hline $\mathrm{F}$ & 32.2 & 1.59 & 39.4 & 1.28 & - & - & - & - & 6 \\
\hline$G$ & 23.8 & 1.46 & 27.4 & 1.24 & 30.9 & 1.17 & 34.2 & 1.05 & 8 \\
\hline $\mathrm{H}$ & 30.0 & 0.96 & 36.7 & 1.22 & - & - & - & - & 6 \\
\hline 1 & 31.7 & 1.36 & 39.1 & 1.18 & - & - & - & - & 6 \\
\hline Mean & & 1.28 & & 1.20 & & 1.18 & & 1.12 & \\
\hline SD & & 0.20 & & 0.19 & & 0.01 & & 0.11 & \\
\hline
\end{tabular}

Table 4. Frequencies and damping ratios of second-order modes for frequencies up to $40 \mathrm{~Hz}$

\begin{tabular}{ccccccccc}
\hline Floor & $\begin{array}{c}f_{2,1} \\
(\mathrm{~Hz})\end{array}$ & $\begin{array}{c}\zeta_{2,1} \\
(\%)\end{array}$ & $\begin{array}{c}f_{2,2} \\
(\mathrm{~Hz})\end{array}$ & $\begin{array}{c}\zeta_{2,2} \\
(\%)\end{array}$ & $\begin{array}{c}f_{2,3} \\
(\mathrm{~Hz})\end{array}$ & $\begin{array}{c}\zeta_{2,3} \\
(\%)\end{array}$ & $\begin{array}{c}f_{2,4} \\
(\mathrm{~Hz})\end{array}$ & $\begin{array}{c}\zeta_{2,4} \\
(\%)\end{array}$ \\
\hline A & 34.2 & 1.73 & 37.2 & 1.86 & 39.1 & 1.19 & - & - \\
B & 35.2 & 1.93 & 37.7 & 1.41 & $(40.1)$ & 1.03 & - & - \\
C & 35.2 & 1.63 & 38.0 & 1.50 & $(40.1)$ & 1.56 & - & - \\
D & 34.8 & 1.45 & 37.6 & 1.23 & $(41.1)$ & 1.15 & - & - \\
E & 35.5 & 1.70 & 37.7 & 1.60 & 40.0 & 1.43 & - & - \\
F & 31.7 & 1.77 & 33.5 & 1.40 & 36.6 & 1.24 & 39.8 & 1.51 \\
G & 37.9 & 1.84 & $(40.7)$ & 1.14 & - & - & - & - \\
H & 38.1 & 1.68 & $(40.6)$ & 1.11 & - & - & - & - \\
I & 34.6 & 2.68 & 37.6 & 1.40 & 39.6 & 1.60 & $(42.3)$ & 0.79 \\
\hline Mean & & 1.73 & & 1.86 & & 1.19 & & 1.15 \\
SD & & 0.35 & & 0.24 & & 0.22 & & - \\
\hline
\end{tabular}


Table 5. Comparison between the calculated and measured fundamental frequencies

\begin{tabular}{lccccccccc}
\hline \multicolumn{1}{c}{ Floor } & $\mathrm{A}$ & $\mathrm{B}$ & $\mathrm{C}$ & $\mathrm{D}$ & $\mathrm{E}$ & $\mathrm{F}$ & $\mathrm{G}$ & $\mathrm{H}$ & $\mathrm{I}$ \\
\hline$L(\mathrm{~mm})$ & 5150 & 5150 & 5150 & 5150 & 5150 & 5150 & 5150 & 5150 & 5150 \\
$B(\mathrm{~mm})$ & 4900 & 4900 & 4900 & 4900 & 4900 & 4900 & 4900 & 4900 & 4900 \\
$S(\mathrm{~mm})$ & 600 & 600 & 600 & 600 & 600 & 600 & 400 & 400 & 400 \\
$I_{\text {y,joist }}\left(\times 10^{6} \mathrm{~mm}^{4}\right)$ & 99.353 & 99.353 & 99.353 & 99.353 & 99.353 & 99.353 & 99.353 & 99.353 & 99.353 \\
$E_{0, \text { mean,TR26 }}\left(\mathrm{N} / \mathrm{mm}^{2}\right)$ & 0 & 10784 & 10784 & 10784 & 10784 & 10784 & 0 & 10784 & 10784 \\
$m\left(\mathrm{~kg} / \mathrm{m}^{2}\right)$ & 23.850 & 24.415 & 24.477 & 24.438 & 24.176 & 33.290 & 28.369 & 28.671 & 37.782 \\
$m^{\prime}\left(\mathrm{kg} / \mathrm{m}^{2}\right)$ & 27.086 & 27.651 & 27.713 & 27.674 & 27.412 & 36.526 & 33.223 & 33.525 & 42.636 \\
$(E l)$ joist $(\mathrm{MNm})$ & 1.0714 & 1.0714 & 1.0714 & 1.0714 & 1.0714 & 1.0714 & 1.0714 & 1.0714 & 1.0714 \\
$(E l)\llcorner(\mathrm{MNm} / \mathrm{m})$ & 1.7857 & 1.7857 & 1.7857 & 1.7857 & 1.7857 & 1.7857 & 2.6786 & 2.6786 & 2.6786 \\
$f_{1, \text { EC5 }}(\mathrm{Hz})$ & 16.2 & 16.0 & 16.0 & 16.0 & 16.1 & 13.7 & 18.2 & 18.1 & 15.8 \\
$f_{1, \text { revised }}(\mathrm{Hz})$ & 15.2 & 15.1 & 15.0 & 15.0 & 15.1 & 13.1 & 16.8 & 16.7 & 14.8 \\
$f_{1, \text { measured }}(\mathrm{Hz})$ & 14.4 & 14.6 & 14.6 & 14.5 & 14.5 & 13.4 & 15.5 & 15.5 & 14.3 \\
$f_{1, \text { EC5 }} / f_{1, \text { measured }}$ & 1.13 & 1.10 & 1.10 & 1.10 & 1.11 & 1.02 & 1.17 & 1.17 & 1.10 \\
$f_{1, \text { revised }} / f_{1, \text { measured }}$ & 1.06 & 1.03 & 1.03 & 1.03 & 1.04 & 0.98 & 1.08 & 1.08 & 1.03 \\
\hline
\end{tabular}


Table 6. Calculated unit impulse velocities for all nine tested floors

\begin{tabular}{|c|c|c|c|c|c|c|c|c|c|}
\hline Floor & A & B & C & $\mathrm{D}$ & E & $\mathrm{F}$ & G & $\mathrm{H}$ & 1 \\
\hline$t_{\text {deck }}(\mathrm{mm})$ & 22 & 22 & 22 & 22 & 22 & 22 & 22 & 22 & 22 \\
\hline$t_{\text {plasterboard }}(\mathrm{mm})$ & 0 & 0 & 0 & 0 & 0 & 12.5 & 0 & 0 & 12.5 \\
\hline$b_{\text {strongback }}(\mathrm{mm})$ & 0 & 47 & 45 & 35 & 35 & 35 & 0 & 47 & 45 \\
\hline$h_{\text {strongback }}(\mathrm{mm})$ & 0 & 147 & 147 & 97 & 97 & 97 & 0 & 147 & 147 \\
\hline$n_{\text {strongback }}$ & 0 & 1 & 1 & 2 & 1 & 1 & 0 & 1 & 1 \\
\hline$I_{\text {deck }(b=1000 \mathrm{~mm})}\left(\times 10^{6} \mathrm{~mm}^{4}\right)$ & 0.8873 & 0.8873 & 0.8873 & 0.8873 & 0.8873 & 0.8873 & 0.8873 & 0.8873 & 0.8873 \\
\hline$I_{\text {plasterboard }}\left(\times 10^{6} \mathrm{~mm}^{4}\right)$ & 0 & 0 & 0 & 0 & 0 & 0.1628 & 0 & 0 & 0.1628 \\
\hline$I_{\text {strongback }}\left(\times 10^{6} \mathrm{~mm}^{4}\right)$ & 0 & 12.441 & 11.912 & 5.3239 & 2.6620 & 2.6620 & 0 & 2.6620 & 2.6620 \\
\hline$E_{\text {mean,P5 }}\left(\mathrm{N} / \mathrm{mm}^{2}\right)$ & 3000 & 3000 & 3000 & 3000 & 3000 & 3000 & 3000 & 3000 & 3000 \\
\hline$E_{\text {plasterboard }}\left(\mathrm{N} / \mathrm{mm}^{2}\right)$ & 2000 & 2000 & 2000 & 2000 & 2000 & 2000 & 2000 & 2000 & 2000 \\
\hline$E_{0, \text { mean,strongback }}\left(\mathrm{N} / \mathrm{mm}^{2}\right)$ & 0 & 11200 & 12669 & 11133 & 12625 & 12625 & 0 & 12057 & 12057 \\
\hline$\rho_{\text {mean,P5 }} \quad\left(\mathrm{kg} / \mathrm{m}^{3}\right)$ & 621.84 & 621.84 & 621.84 & 621.84 & 621.84 & 621.84 & 621.84 & 621.84 & 621.84 \\
\hline$\rho_{\text {mean,plasterboard }}\left(\mathrm{kg} / \mathrm{m}^{3}\right)$ & 651.39 & 651.39 & 651.39 & 651.39 & 651.39 & 651.39 & 651.39 & 651.39 & 651.39 \\
\hline$(E /)_{\text {deck }}\left(\mathrm{Nm}^{2} / \mathrm{m}\right)$ & 2.662 & 2.662 & 2.662 & 2.662 & 2.662 & 2.662 & 2.662 & 2.662 & 2.662 \\
\hline$(E I)_{\text {plasterboard }}\left(\mathrm{kNm}^{2} / \mathrm{m}\right)$ & 0 & 0 & 0 & 0 & 0 & 0.326 & 0 & 0 & 0.326 \\
\hline$(E /)_{\text {strongback }}\left(\mathrm{kNm}^{2} / \mathrm{m}\right)$ & 0 & 27.057 & 29.303 & 11.509 & 6.526 & 6.526 & 0 & 6.232 & 6.232 \\
\hline$(E /)_{\mathrm{B}}\left(\mathrm{kNm}^{2} / \mathrm{m}\right)$ & 2.662 & 29.719 & 31.965 & 14.171 & 9.188 & 9.513 & 2.662 & 8.894 & 9.220 \\
\hline$b_{0}$ & 105.48 & 105.48 & 105.48 & 105.48 & 105.48 & 105.48 & 105.48 & 105.48 & 105.48 \\
\hline$n_{40, \text { calculated }}$ & 7.3 & 4.0 & 3.9 & 4.8 & 5.4 & 5.8 & 7.5 & 5.6 & 6.0 \\
\hline$n_{40, \text { measured }}$ & 8 & 5 & 5 & 5 & 6 & 6 & 8 & 6 & 6 \\
\hline$v\left(\mathrm{~m} / \mathrm{Ns}^{2}\right)$ & 0.0238 & 0.0138 & 0.0135 & 0.0161 & 0.0179 & 0.0150 & 0.0214 & 0.0162 & 0.0139 \\
\hline$\zeta$ EC5 & 0.01 & 0.01 & 0.01 & 0.01 & 0.01 & 0.01 & 0.01 & 0.01 & 0.01 \\
\hline ¿UKNA & 0.02 & 0.02 & 0.02 & 0.02 & 0.02 & 0.02 & 0.02 & 0.02 & 0.02 \\
\hline Smeasured & 0.0088 & 0.0083 & 0.0088 & 0.0087 & 0.0079 & 0.0099 & 0.0077 & 0.0094 & 0.0080 \\
\hline$b^{\left(\mathrm{f}_{i} ;-1\right)}(\mathrm{EC} 5-1-1)\left(\mathrm{m} / \mathrm{Ns}^{2}\right)$ & 0.0202 & 0.0200 & 0.0200 & 0.0200 & 0.0201 & 0.0180 & 0.0221 & 0.0220 & 0.0198 \\
\hline$b^{\left(\mathrm{f}_{i} ;-1\right)}(\mathrm{UK} \mathrm{NA}) \quad\left(\mathrm{m} / \mathrm{Ns}^{2}\right)$ & 0.0429 & 0.0422 & 0.0421 & 0.0421 & 0.0425 & 0.0340 & 0.0517 & 0.0512 & 0.0412 \\
\hline$b^{(\mathrm{fi}[-1)}($ measured $)\left(\mathrm{m} / \mathrm{Ns}^{2}\right)$ & 0.0171 & 0.0167 & 0.0172 & 0.0171 & 0.0162 & 0.0176 & 0.0166 & 0.0187 & 0.0161 \\
\hline$\lambda_{\mathrm{v}, \mathrm{EC} 5}$ & 1.18 & 0.69 & 0.68 & 0.81 & 0.89 & 0.84 & 0.97 & 0.74 & 0.70 \\
\hline$\lambda_{\mathrm{v}, \mathrm{UKNA}}$ & 0.55 & 0.33 & 0.32 & 0.38 & 0.42 & 0.44 & 0.41 & 0.32 & 0.34 \\
\hline$\lambda_{v, \text { measured }}$ & 1.39 & 0.825 & 0.79 & 0.95 & 1.10 & 0.85 & 1.29 & 0.87 & 0.86 \\
\hline Remarks on $\lambda_{\mathrm{v}, \mathrm{EC} 5}$ & Fail & Pass & Pass & Pass & Pass & Pass & Pass & Pass & Pass \\
\hline Remarks on $\lambda_{\mathrm{v}, \mathrm{UK} N \mathrm{NA}}$ & Pass & Pass & Pass & Pass & Pass & Pass & Pass & Pass & Pass \\
\hline Remarks on $\lambda_{v \text {,measured }}$ & Fail & Pass & Pass & Pass & Fail & Pass & Fail & Pass & Pass \\
\hline
\end{tabular}


Table 7. Comparison between the calculated and measured maximum displacements

\begin{tabular}{lccccccccc}
\hline \multicolumn{1}{c}{ Floor } & $\mathrm{A}$ & $\mathrm{B}$ & $\mathrm{C}$ & $\mathrm{D}$ & $\mathrm{E}$ & $\mathrm{F}$ & $\mathrm{G}$ & $\mathrm{H}$ & $\mathrm{I}$ \\
\hline$L_{\text {eq }}(\mathrm{mm})$ & 5150 & 5150 & 5150 & 5150 & 5150 & 5150 & 5150 & 5150 & 5150 \\
$k_{\text {dist }}$ & 0.480 & 0.300 & 0.300 & 0.336 & 0.369 & 0.366 & 0.350 & 0.300 & 0.300 \\
$k_{\text {amp }}$ & 1.3 & 1.3 & 1.3 & 1.3 & 1.3 & 1.3 & 1.3 & 1.3 & 1.3 \\
$k_{\text {strut }}$ & 1 & 0.97 & 0.97 & 0.97 & 0.97 & 0.97 & 1 & 0.97 & 0.97 \\
$(E l)$ joist $\left(\times 10^{12} \mathrm{Nmm}^{2} / \mathrm{m}\right)$ & 1.0714 & 1.0714 & 1.0714 & 1.0714 & 1.0714 & 1.0714 & 1.0714 & 1.0714 & 1.0714 \\
$(E l)_{\mathrm{b}, \text { eff }}\left(\times 10^{9} \mathrm{Nmm} / \mathrm{m}\right)$ & 2.6620 & 29.719 & 31.965 & 14.171 & 9.1877 & 9.5132 & 2.6620 & 8.8941 & 9.2196 \\
$w_{\text {calculated }}(\mathrm{mm} / \mathrm{kN})$ & 1.66 & 1.04 & 1.04 & 1.16 & 1.28 & 1.27 & 1.21 & 1.04 & 1.04 \\
$w_{\text {measured }}(\mathrm{mm} / \mathrm{kN})$ & 1.80 & 1.11 & 1.08 & 1.28 & 1.25 & 0.97 & 1.44 & 0.96 & 0.86 \\
$a(\mathrm{~mm} / \mathrm{kN})$ & 1.36 & 1.36 & 1.36 & 1.36 & 1.36 & 1.36 & 1.36 & 1.36 & 1.36 \\
$w_{\text {calculated }} / \mathrm{a}$ & 1.215 & 0.760 & 0.760 & 0.850 & 0.935 & 0.928 & 0.887 & 0.760 & 0.760 \\
$w_{\text {measured }} / \mathrm{a}$ & 1.318 & 0.811 & 0.789 & 0.936 & 0.918 & 0.708 & 1.057 & 0.707 & 0.631 \\
Remarks on $w_{\text {calculated }} / \mathrm{a}$ & Fail & Pass & Pass & Pass & Pass & Pass & Pass & Pass & Pass \\
Remarks on $w_{\text {measured }} / \mathrm{a}$ & Fail & Pass & Pass & Pass & Pass & Pass & Fail & Pass & Pass \\
\hline
\end{tabular}




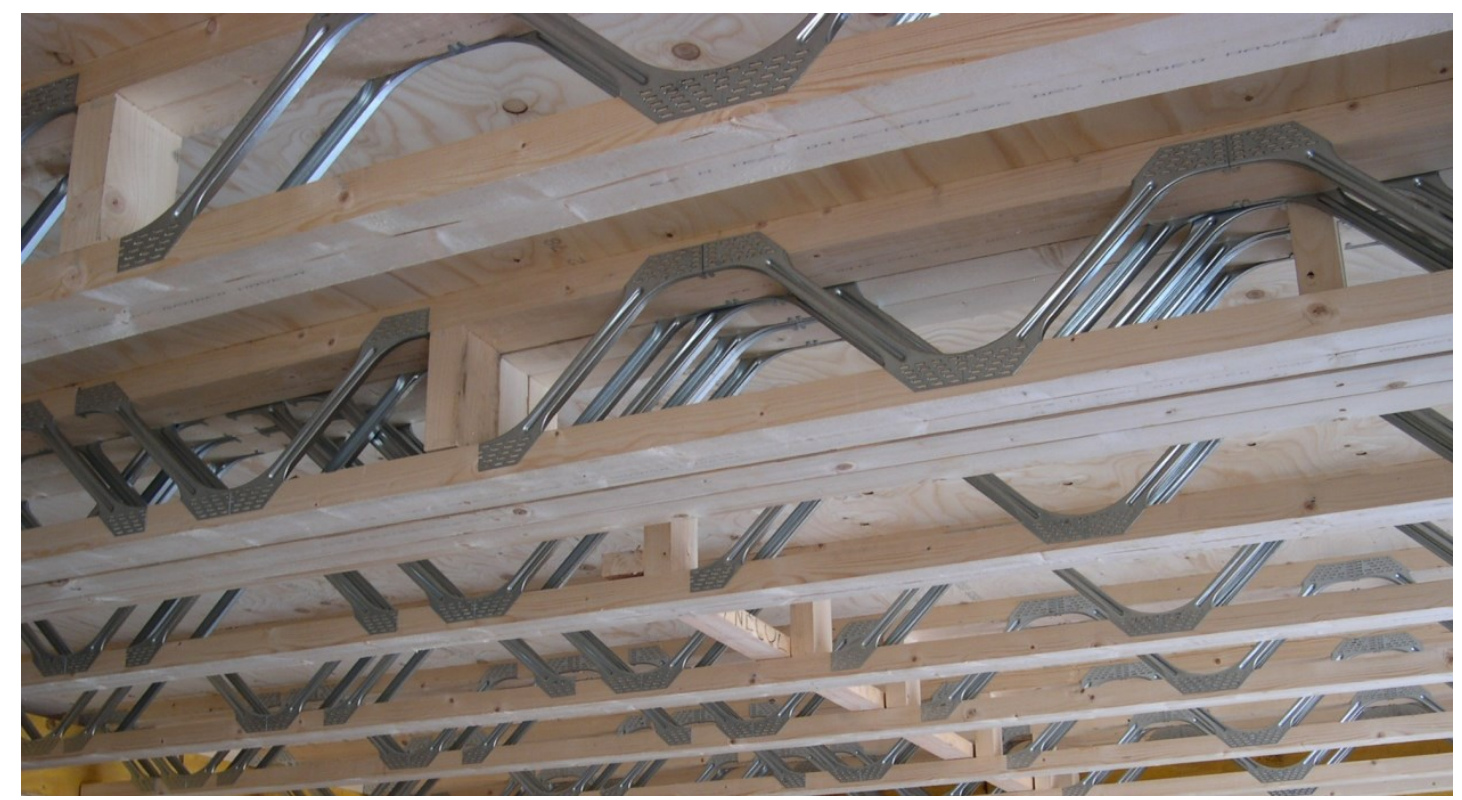

Figure 1. Applications of metal web joists for constructing floors (PS09 Posi-Joists)

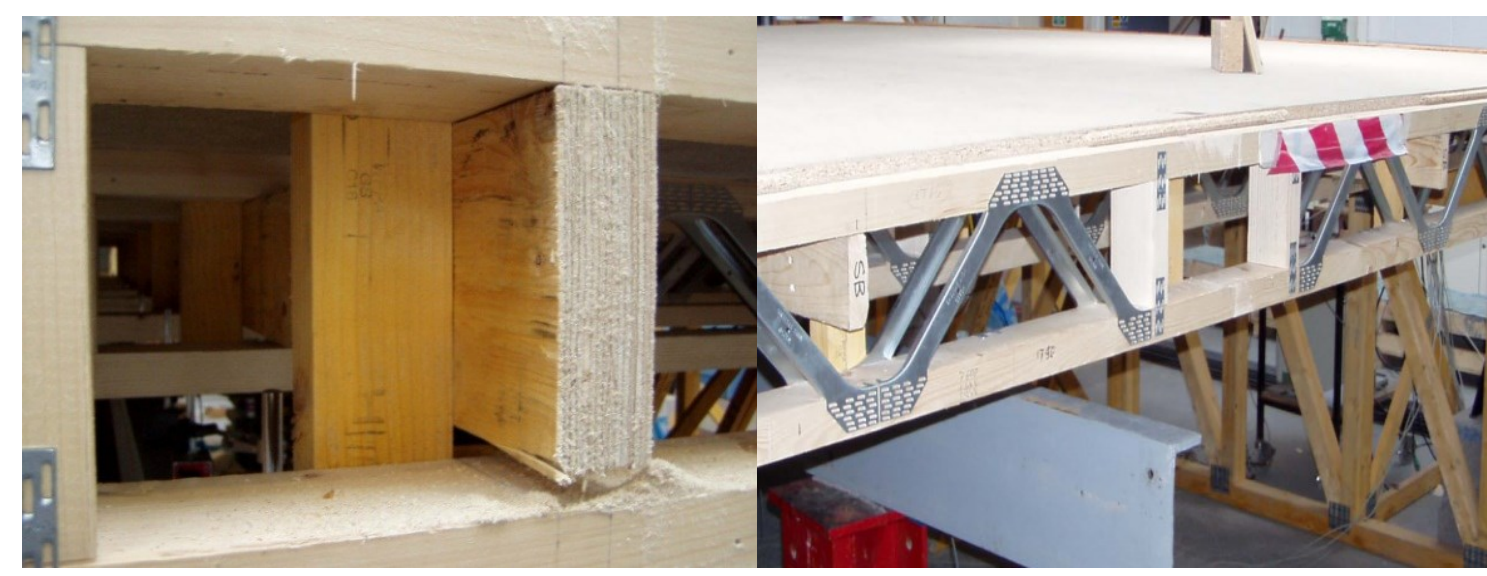

(a) $45 \mathrm{~mm} \times 147 \mathrm{~mm}$ Kerto $\mathrm{S}$ strongback at mid-span in Floor $\mathrm{C}$

(b) $35 \mathrm{~mm} \times 97 \mathrm{~mm}$ TR26 strongbacks at one-third spans in Floor $D$

Figure 2. Typical floors stiffened with strongbacks 


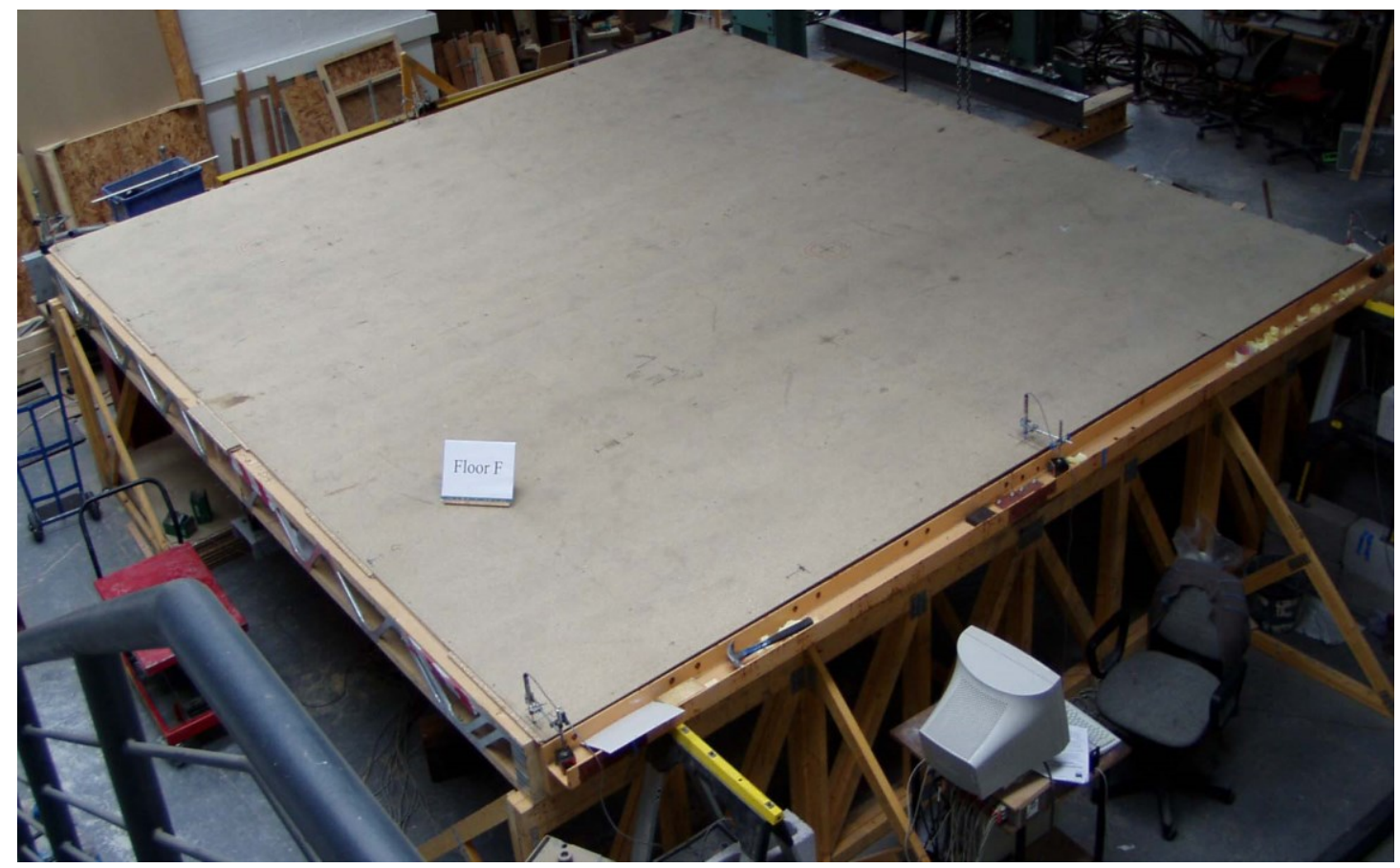

Figure 3. A typical metal web joist floor of $5.15 \mathrm{~m} \times 5.0 \mathrm{~m}$ (Floor F)

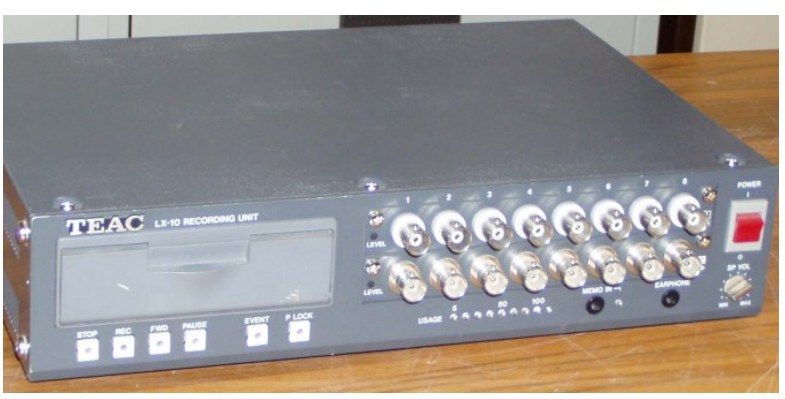

(a) TEAC data recorder

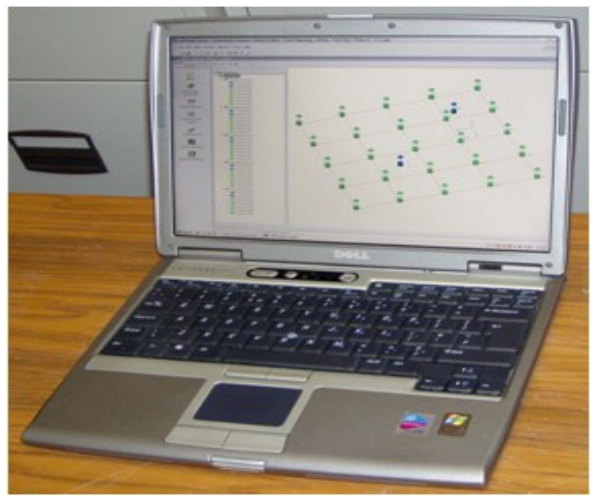

(c) Laptop with modal analysis software package

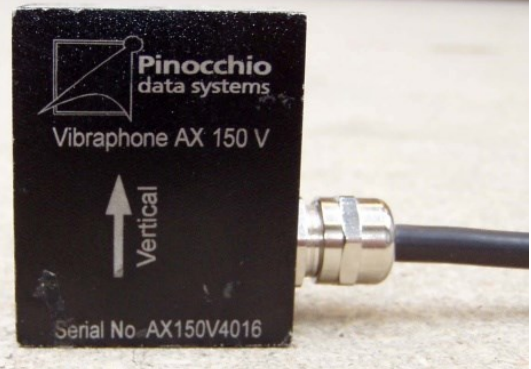

(b) Pinocchio vibraphone accelerometer

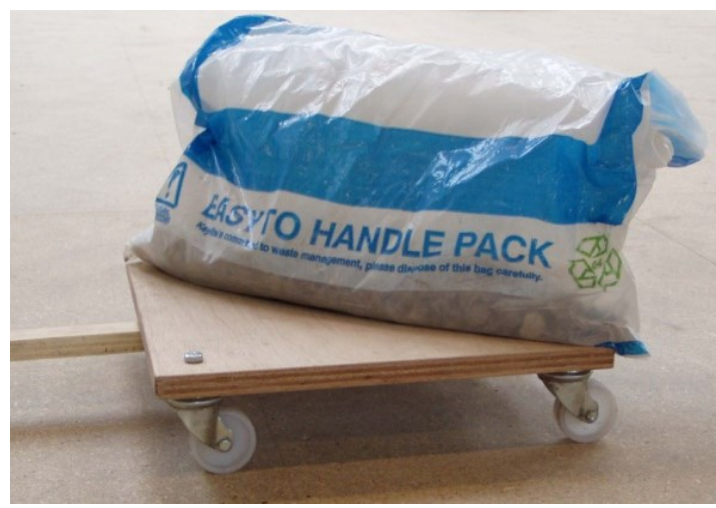

(d) Trolley with the attached weight

Figure 4. Equipment used for vibrational performance testing 


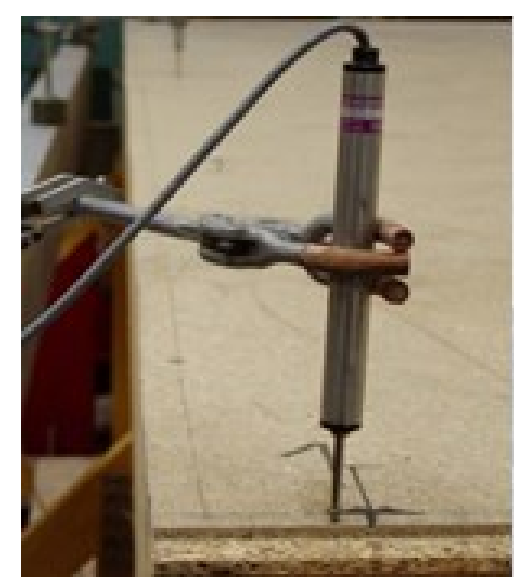

(a) LVDT

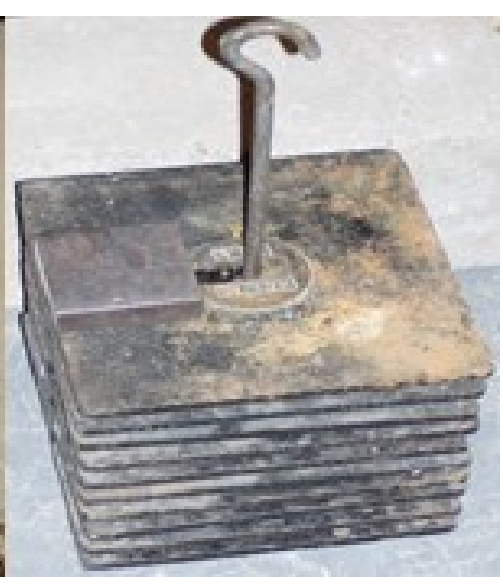

(b) Steel plates

Figure 5. Test equipment for measuring deflections under unit point load

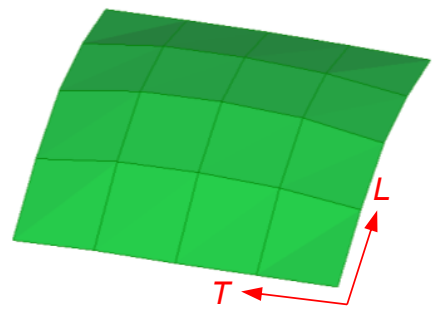

Mode 1-1:

$f_{1,1}=14.3 \mathrm{~Hz}, \zeta_{1,1}=0.80 \%$

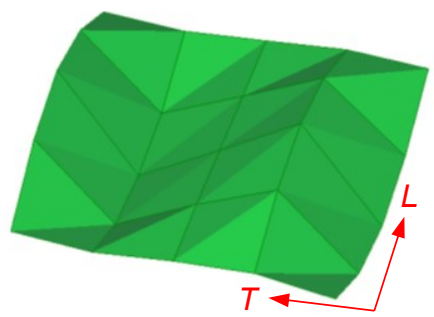

Mode 1-4:

$f_{1,4}=24.7 \mathrm{~Hz}, \zeta_{1,4}=1.19 \%$

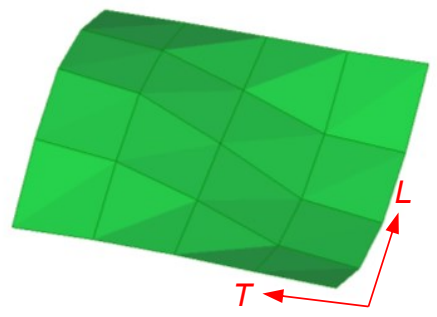

Mode 1-2:

$f_{1,2}=16.2 \mathrm{~Hz}, \zeta_{1,2}=0.73 \%$

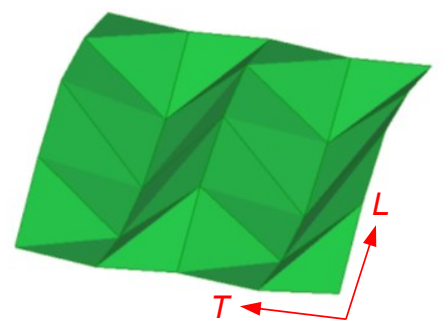

Mode 1-5:

$f_{1,5}=31.7 \mathrm{~Hz}, \zeta_{1,5}=1.36 \%$

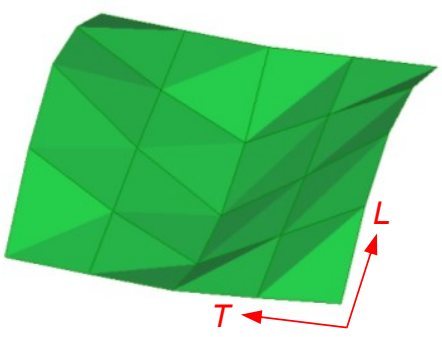

Mode 1-3:

$f_{1,3}=19.7 \mathrm{~Hz}, \zeta_{1,3}=0.98 \%$

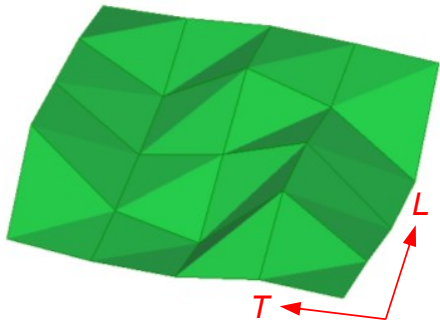

Mode 1-6:

$f_{1,6}=39.1 \mathrm{~Hz}, \zeta_{1,6}=1.18 \%$

Figure 6. First-order mode shapes of a typical floor (Floor I) 


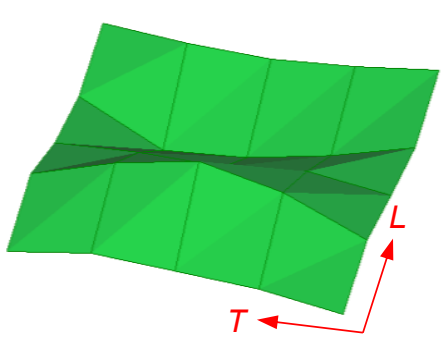

Mode 2-1:

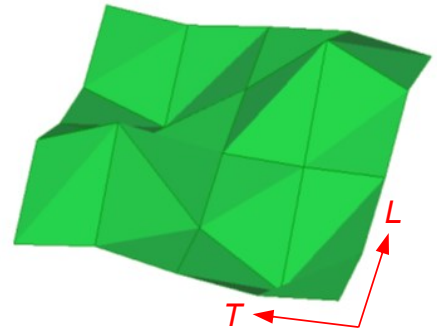

Mode 2-2:

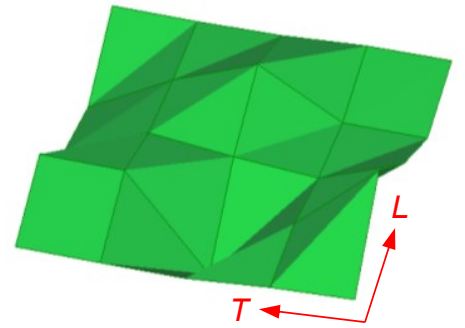

Mode 2-3:

$f_{2,1}=34.6 \mathrm{~Hz}, \zeta_{2,1}=2.68 \% \quad f_{2,2}=37.6 \mathrm{~Hz}, \zeta_{2,2}=1.40 \% \quad f_{2,3}=39.6 \mathrm{~Hz}, \zeta_{2,3}=1.60 \%$

Figure 7. Second-order mode shapes of a typical floor (Floor I)

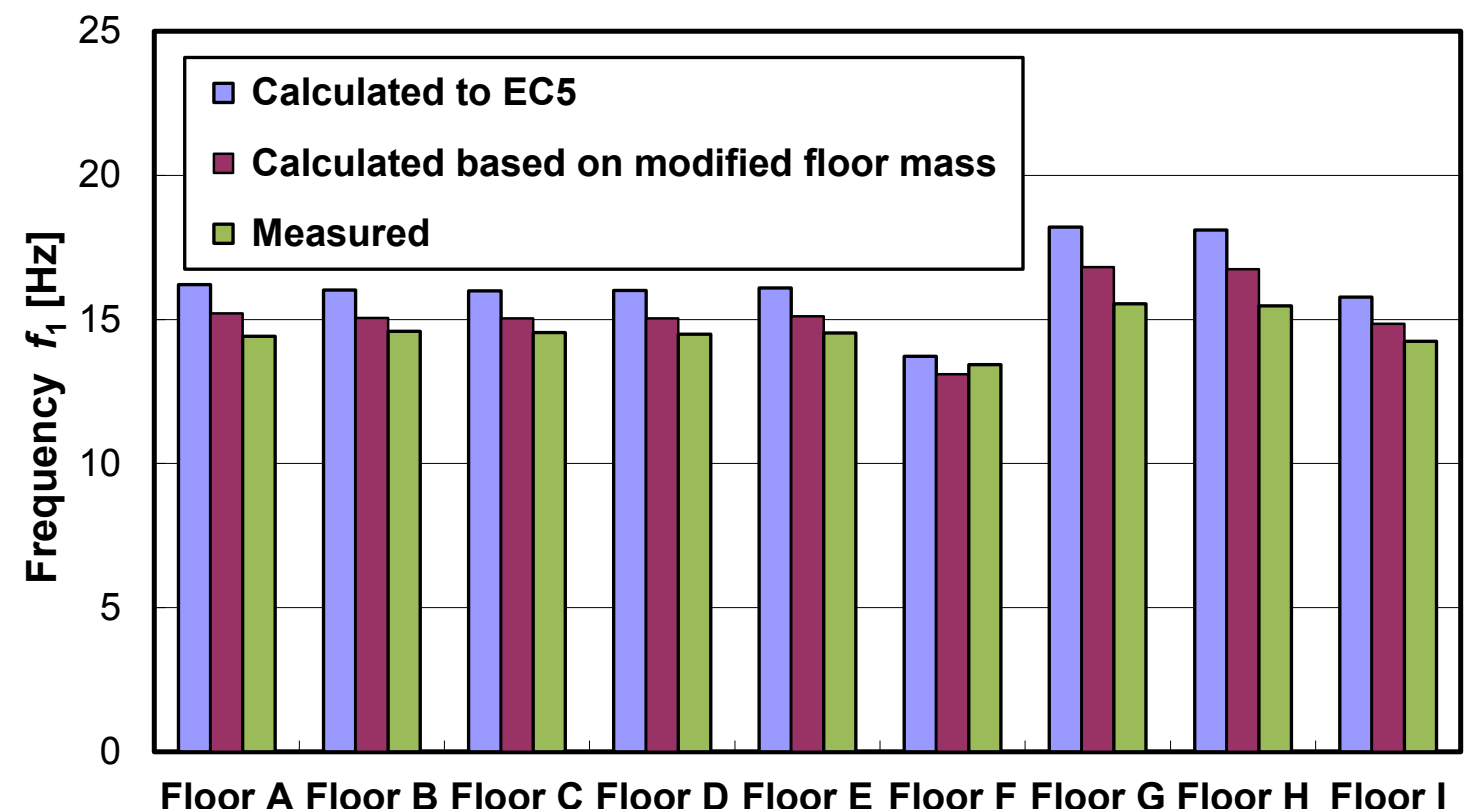

Figure 8. Fundamental frequencies calculated and measured for all tested floors 


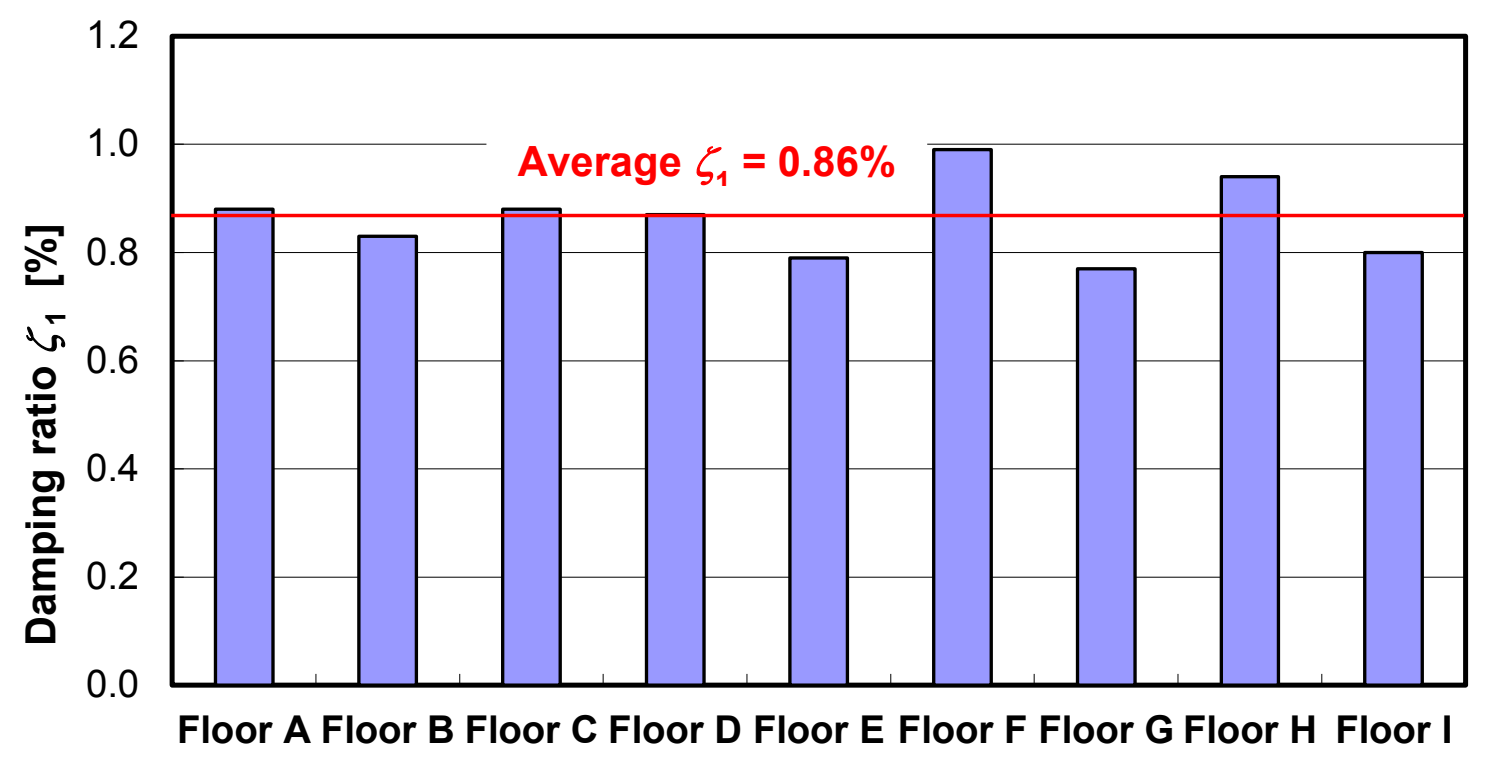

Figure 9. Measured Mode 1-1 damping ratio $\zeta_{1}$ for metal web joist floors

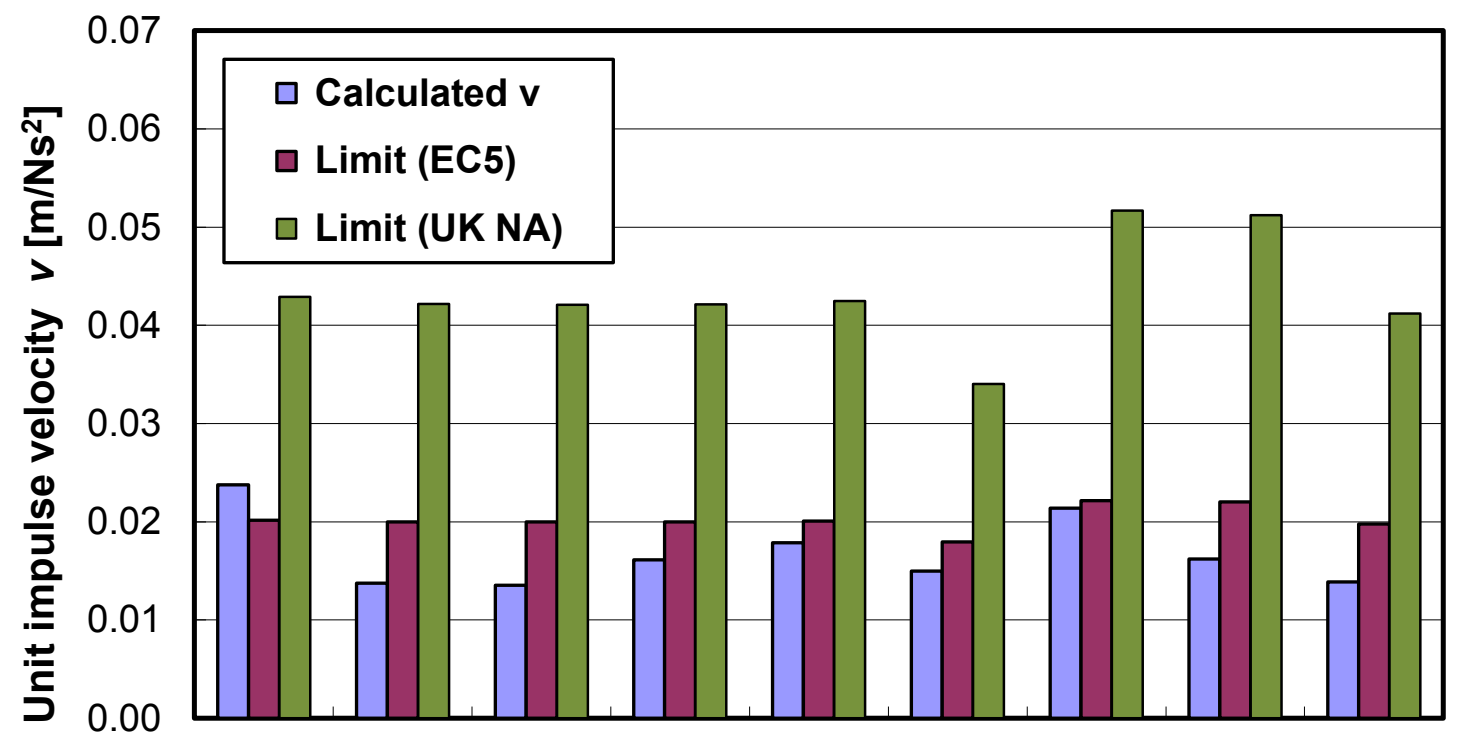

Floor AFloor B Floor CFloor D Floor E Floor F Floor GFloor H Floor I

Figure 10. Calculated unit impulse velocities of tested floors and the recommended design limits in EC5-1-1 and the UK NA to EC5-1-1 


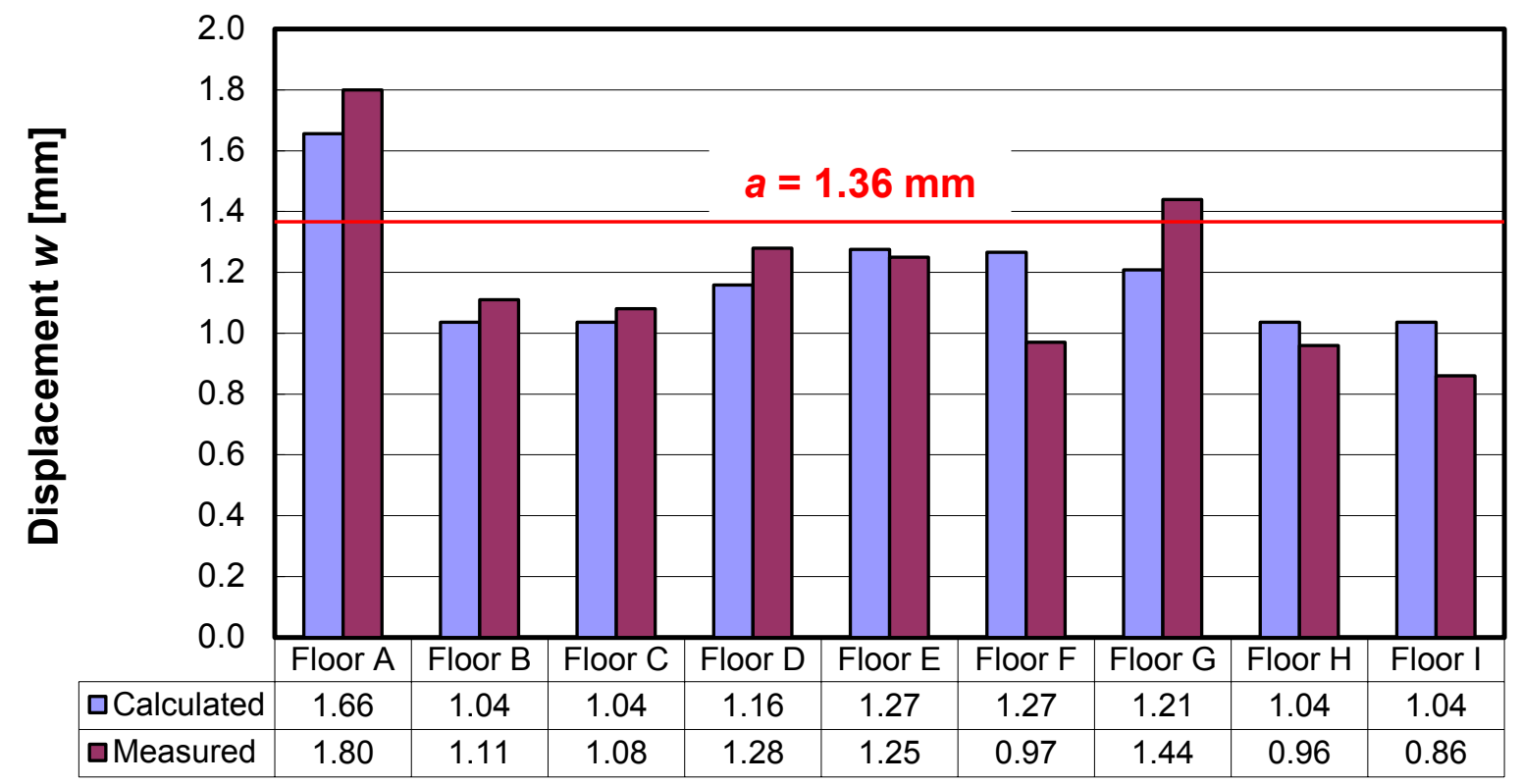

Figure 11. Measured and calculated maximum displacements under $1 \mathrm{kN}$ point load for all tested floors 